NBER WORKING PAPER SERIES

\title{
ALCOHOL ADVERTISING \\ AND MOTOR VEHICLE FATALITIES
}

Henry Saffer

Working Paper No. 4708

\section{NATIONAL BUREAU OF ECONOMIC RESEARCH 1050 Massachusetts Avenue \\ Cambridge, MA 02138 \\ April 1994}

I would like to thank Michael Grossman and Frank Chaloupka for their many helpful comments on earlier drafts of this paper. I would also like to thank Christopher Ruhm and Donald Kenkel for helpful comments, and Geoffrey Joyce and Patricia DeVries for their assistance in preparing the data used in this study. This paper was funded by Grant Number 5 RO1 AA08349 from the National Institute on Alcohol Abuse and Alcoholism. This paper is part of NBER's research program in Health Economics. Any opinions expressed are those of the author and not those of the National Bureau of Economic Research. 


\title{
ALCOHOL ADVERTISING AND MOTOR VEHICLE FATALITIES
}

\begin{abstract}
The purpose of this paper is to empirically estimate the effect of alcohol advertising on motor vehicle fatalities. The concept of an industry level advertising response function is developed and other empirical issues in estimating the effects of advertising are reviewed. The data set consists of quarterly observations, from 1986 to 1989 , for 75 advertising markets in the United States and includes 1200 observations. Since motor vehicle fatalities and alcohol advertising are jointly determined, Two Stage Least Squares is used in the estimation. Reduced form fatality models and advertising models are also estimated to predict the effect of changes in the price of advertising. The regression results show that alcohol advertising has a significant and positive effect on motor vehicle fatalities. The data and regression results are used to estimate the effects of two policy options. The first option is to ban all broadcast alcohol advertising. The data indicate that if a ban on broadcast alcohol advertising did not also include bans on other types of alcohol marketing, the effect on motor vehicle fatalities might be in the range of 2000 to 3000 lives saved per year. The second policy is the elimination of the tax deductibility of alcohol advertising. This policy could reduce alcohol advertising by about 27 percent, reduce motor vehicle fatalities by about 2300 deaths per year and raise about $\$ 336$ million a year in new tax revenue.
\end{abstract}

Henry Saffer National Bureau of Economic Research 269 Mercer Street

Eighth Floor

New York, NY 10003 


\section{Introduction}

Public health advocates have expressed concern that alcohol advertising may be a factor contributing to the high number of motor vehicle fatalities in the United States. The National Institute on Alcoholism and Alcohol Abuse (1990) estimated that in 1987, over 42 percent of the 46,386 motor vehicle fatalities were alcohol involved. Advertising industry sources (Leading National Advertisers, 1991) estimated that in 1990 alcohol producers spent over one billion dollars on mass media advertising. Although the role of alcohol in motor vehicle fatalities is well established and the substantial level of alcohol advertising is well documented, the link between motor vehicle fatalities and alcohol advertising remains a controversial subject.

The appropriateness of broadcast advertising by the alcoholic beverage industry has been debated for some time. As part of the arrangements to end prohibition, spirits producers agreed not to use broadcast advertising. This agreement did not extend to beer and wine producers. In 1939, the Senate Interstate Commerce Committee held hearings on a bill which would have prohibited advertising of alcoholic beverages on the radio. According to Hernon and Ganey (1991) those testifying in favor of the bill asserted that radio advertising contributed to motor vehicle fatalities and that college aged young people were especially targeted for this advertising. In 1976, the Hathaway congressional subcommittee held hearings to investigate the effects of alcohol advertising. Also in 1985, the United States Senate Subcommittee on Alcoholism and Drug Abuse held hearings to examine the issue of broadcast advertising of beer and wine. ${ }^{1}$ In December 1988, the issue of alcohol advertising again received national attention. At that time,

'Also, in 1978 and again in 1980, the Bureau of Alcohol, Tobacco, and Firearms asked for public comment on proposed changes to rules concerning alcohol advertising. 
the Surgeon General of the United States, C. Everett Koop, held a two day workshop to discuss the effect of alcohol advertising on alcohol abuse and drunk driving. In November 1991, the Surgeon General of the United States asked the alcohol producers to voluntarily end advertising aimed at youth. Several members of Congress have recently called for warning statements to accompany all alcohol advertisements. The alcohol producers claim they will stop advertising before paying for warning statements.

The central issue in this debate over alcohol advertising is whether the effect of alcohol advertising is limited to brand choice or whether alcohol advertising also increases total alcohol consumption. The position of public health advocates is that alcohol advertising is designed to foster the belief that alcohol consumption is the key to achieving personal success. Public health advocates contend that alcohol advertising increases total alcohol consumption, and drunk driving and that young people are particularly vulnerable to these advertisements. The position of the alcohol advertisers is that alcohol advertising only induces brand switching and has no effect on overall consumption. The alcohol advertisers also contend that alcohol advertisements follow a strict code, which does not allow them to depict over-consumption nor target the underaged.

The purpose of this paper is to empirically examine the relationship between alcohol advertising and motor vehicle fatalities. There are three novel features of this study which distinguish it from other alcohol advertising studies. The first novel feature is the use of motor vehicle fatalities as the outcome measure. Prior studies have examined the effects of alcohol advertising on alcohol consumption, but no prior study has examined the effect of alcohol 
advertising directly on motor vehicle fatalities. ${ }^{2}$ The second novel feature of this study is the use the of a market specific price of advertising. ${ }^{3}$ This variable is important in the treatment of simultaneity bias and in estimating the price elasticity of alcohol advertising. The third novel feature of this study is use of metropolitan areas as the unit of observation. Almost all prior studies have used national aggregates. The use of metropolitan areas adds an important cross sectional variance to the data. The use of metropolitan areas also increases the number of observations in the data set to more conventionally acceptable levels than data sets used in prior alcohol advertising studies.

\section{Econometric Issues}

There have been a number of prior econometric studies of the effects of alcohol advertising. Since these studies have generally found little evidence of any effect of alcohol advertising, it is important to carefully consider the econometric issues involved in this type of study. This section will outline several important specification issues and examine how these issues have been treated in prior studies. Berndt $(1991$, ch.8) provides additional elaboration of some of these issues.

\subsection{The Industry Level Response Function}

The most important econometric issue in the estimation of the effect of alcohol advertising involves specification of the relationship between industry level alcohol advertising

3 One exception to this is Saffer (1991). This study examined the effect of alcohol advertising bans on alcohol consumption, liver cirrhosis and highway fatalities. The data were annual narional aggregates and included 17 OECD countries over 14 years.

${ }^{3}$ Other studies of advertising use a national level advertising price index. See for example Ehrlich and Fisher (1982). 
and total alcohol consumption. The relationship between advertising and consumption is known as a response function. Industry level alcohol advertising is defined as the sum of all brand level advertising. An industry level response function shows the relationship between industry level advertising and total consumption. The industry level response function, and its implications for estimation, have not been discussed in prior econometric studies.

Some insight into the nature of an industry response function may be found in brand level studies of advertising response functions. Research on advertising response functions is at the brand level since almost all advertising is done at the brand level. The consensus of brand level research is that, ceteris paribus, advertising increases brand level sales and that these increases are subject to diminishing returns. A study by Ackoff and Emshoff (1975) contirms this relationship for specific brands of beer. Brand level advertising response functions hold constant all other determinants of brand level sales including advertising by rivals and product price. At the brand level, new sales induced by advertising come from either increases in market share or increases in market size, or both.

The industry level alcohol advertising response function is hypothesized to also be positively sloped and subject to diminishing returns. This response function holds constant other determinants of industry level sales including advertising by other industries and product prices. This function assumes that industry advertising increases market size and that the effect is subject to diminishing returns.

A more complete discussion of the industry level response function can be made if cigarette advertising, counteradvertising and advertising bans are also included. Cigarette advertising studies are important since the empirical evidence provides an additional test of the 
industry level response function concept. Counteradvertising is defined as the use of the mass media to promote more healthy behaviors. Evidence from cigarette counteradvertising studies is important since there are very few alcohol counteradvertising studies. Advertising bans are important to include since bans limit media choices and can affect the average product of aggregate advertising as well as the marginal product of advertising in non-banned media.

Prior econometric studies of alcohol and cigarette advertising have measured the effect of advertising expenditures, counteradvertising expenditures and advertising bans. Studies that have investigated advertising expenditures have found little evidence that advertising increases consumption. There have been a number of cigarette counteradvertising studies which clearly show that counteradvertising has a negative effect on cigarette consumption. Studies that have investigated advertising bans have found that advertising bans reduce consumption. These seemingly contradictory results can be explained by the industry response function.

The hypothesized industry level alcohol advertising response function is illustrated in figure 1. This figure has total consumption on the vertical axis and aggregate adrertising on the horizontal axis. The function is drawn to show that industry level advertising increases consumption and is subject to diminishing marginal product. The affect of an advertising ban is shown as a downward shift of the response function. A ban on one or more media may initially increase the marginal product of the remaining media. However if the industry substitutes other media for the banned media, then the marginal product in these media will be driven downward. This lowers the marginal product of the remaining media and lowers the average product of aggregate advertising. Whether this function accurately characterizes the

4 Saffer (1994) reviews some of these studies. 
nature of the relationship between industry level alcohol advertising and alcohol consumption depends on the results from empirical studies.

One category of empirical studies measure alcohol and cigarette advertising with annual national advertising expenditures. Advertising expenditure studies of this type show no effect of advertising on consumption. Since alcohol and cigarettes are among the most heavily advertised consumer goods, it is likely that aggregate industry advertising is in the range of near zero marginal returns. The range of near zero marginal returns corresponds to a range around $A_{1}$ range in figure 1 . Since the function is relatively flat in this range there will be no clear relationship between advertising and consumption found in the econometric results.

A second category of econometric studies includes studies of alcohol and cigarelte advertising bans on consumption. The imposition of a ban on the use of one or more media will increase the marginal product of advertising in the remaining media. However, a ban itself will not reduce the demand for advertising and substitution to other media and other forms of marketing is likely." As the remaining media are used more intensively, the marginal products of these media will fall. This results in lower average product of a given aggregate advertising level. ${ }^{6}$ In figures 1 and 2 this is shown as a shift downward of the industry advertising response function. The empirical evidence from several studies of the broadcast advertising ban

3 Other forms of marketing include sports and cultural event sponsorships, consumer novelties, in-store displays, clothing with brand names, closed circuit television in public places, product placements, and direct marketing.

- A ban could also reduce consumption by signaling to individuals that the collective perception is that alcohol has potentially adverse health consequences. An advertising ban could thus act as a type of counteradvertising and reduce alcohol consumption even if aggregate advertising is not reduced. 
on cigarettes in the U.S. and international studies of alcohol and cigarette advertising bans shows that bans reduce consumption.

A third category includes studies of counteradvertising on consumption. Counteradvertising is subject to the same diminishing marginal product as advertising. A counteradvertising response function is illustrated in figure 2. However, the level of counteradvertising is relatively low so that empirical measurement occurs in a range where the marginal product is significant. Studies of counteradvertising are likely to measure advertising in a range around $0-\mathrm{CA}_{1}$ in figure 2 . In this range the function has a measurable negative slope. Counteradvertising studies find that counteradvertising is effective in reducing consumption.

As a group, the results from these three types of advertising studies are provide empirical evidence that the industry response function is positive, subject to diminishing marginal product. and shifts downwards the result of advertising bans. One implication of these results is that empirical studies of industry level advertising of alcohol or cigarettes should employ advertising data that cover a large variation in advertising. The empirical strategy used in this paper is to employ a data set with advertising originating on the cross sectional level. Cross sectional studies of advertising are more likely to measure advertising in a range between $0-A_{1}$ in figure 1 and thus reveal, if it exists, the positive relationship between advertising and consumption.

\subsection{Other Econometric Issues}

The second econometric issue is simultaneity between advertising and consumption. Some economists (see Schmalensee, 1972) argue that, for mature products, advertising budgets are adjusted so that advertising expenditure is a fixed percentage of consumption. On the other hand, firms undertake advertising so that they can increase consumption. These assumptions 
imply that advertising and consumption are jointly determined. If this is the case, OLS estimation will be biased and a two stage estimation model is needed. A two stage estimation model must have a structural consumption equation and structural advertising equation. The structural advertising equation is a demand for advertising. Both structural equations must be identified by at least one exogenous variable that does not appear in the other equation. Identification of the consumption equation is achieved relatively easily with product price and other variables. The advertising structural equation is harder to identify. In this study, advertising price and the number of TV stations and radio stations are used.

The third econometric issue in estimating the relationship between alcohol consumption and advertising is temporal aggregation bias. Temporal aggregation bias refers to bias resulting from the length of the time interval used to measure the data. Aggregation over a long interval, such as a year, may obscure important variance in the dependent and independent variables. Alcohol advertising expenditures follow a seasonal pattern and also vary during the year due to expenditure pulsing schedules. Expenditure pulsing is a widely use technique of spending a given annual budget in short intense intervals of advertising rather than maintaining a constant level of spending throughout the year. The effects of these expenditure pulses may linger for a month or more and result maximizing the effect of the given budget. In both the case of seasonal spending and pulsing, annual data will not measure these important variations in expenditure and any resulting influence on consumption.

The last econometric issue involves the measurement of advertising. In estimation using aggregate data, the advertising variable should measure the number of effective advertising messages in the aggregation group. Effectiveness refers to the number of people exposed to an 
advertising message and the impact of the message.

\subsection{The Evidence from Prior Studies}

The largest category of prior econometric studies are those which measure advertising by advertising expenditure. These studies find no consistent effect of advertising on total alcohol consumption. The second category uses advertising bans as the measure of advertising. To measure the effect of a ban, a control group or period with no ban, is needed. In the case of a time series, a long period may be needed for adjustment to a ban. In the case of an alternative aggregate, appropriate controls for other factors are necessary. The effects of advertising bans have been studied with interrupted time series techniques and with regression models. Some of these studies have found that advertising effects alcohol use. A more detailed review of prior studies including cigarette advertising studies is provided by Saffer (1994).

In the advertising expenditure category, one group of studies relies on a short time series of annual data from one country. The annual nature of the data and the small sample sizes are problems. These studies generally account for non-linearity and simultaneity. Studies by Comanor and Wilson (1974), Grabowski (1976), McGuiness (1980, 1983), Walsh (1982), Duffy (1983, 1987), Johnson (1985) and Selvanathan (1989) are representative of this group. These studies represent important efforts in estimating the effects of alcohol advertising. The results are, however, weak and inconsistent.

Three additional expenditure studies improve upon the data problems somewhat. A study by Duffy (1991) and a study by Franke and Wilcox (1987) use quarterly data. Another study by Bourgeois and Barnes (1979) adds some cross sectional data. These studies variously account for non-linearities, temporal aggregation bias but not simultaneity and do not provide any 
evidence that advertising has any effect on consumption.

Studies of alcohol advertising bans using interrupted time series techniques were done by Smart and Cutler (1976) and Ogborne and Smart (1980). These studies examine the effect of advertising bans in British Columbia and Manitoba, respectively. The ban in British Columbia included all alcohol advertising but lasted only one year. The ban in Manitoba included only beer advertising and was analyzed using an eight year time series. Both studies concluded that these advertising bans had no effect on alcohol consumption. Alternatively, these results may indicate that in a single province or country study a long time period is necessary before there is any observable change in alcohol consumption.'

Another sludy of advertising bans was done by Ornstein and Hanssens (1985). They examine the effect of bans on outdoor advertising, bans on consumer novelties and bans on price advertising on beer and spirits consumption in the United States. State data for the period 1974 to 1978 is used. The results show that states that allow price advertising and consumer novelties have higher spirits consumption. They also find that outdoor advertising and novelties have no effect on beer consumption while there is some evidence that price advertising increases beer consumption.

Saffer (1991) examines the effect of banning broadcast advertising of alcoholic beverages on alcohol abuse. ${ }^{8}$ This study contains the first set of estimates, using international data, of the effect of television advertising bans on alcohol abuse. The effect of a ban is difficult to estimate

1 The provincial bans may not have resulted in much of a reduction in total advertising exposure since these provinces receive a considerable amount of television programming from the U.S.

${ }^{8}$ See also Young (1993) and Saffer (1993). 
using data from one country because the adoption of new advertising bans is an infrequent event and requires many years for adjustment. However, an international data set can be used since there is considerable variation in the use of advertising bans across countries. The data used in this study are a pooled time series from 17 countries for the period 1970 to 1983 . The empirical measures of alcohol abuse are alcohol consumption, liver cirrhosis mortality rates, and motor vehicle fatality rates. The many cultural factors which influence alcohol use are measured by alcohol production variables and a set of country dummy variables. The empirical results show that both alcohol advertising bans and alcohol price can have a significant effect in reducing alcohol abuse.

\section{The Empirical Model}

In this study, to test the potential endogeneity between motor vehicle fatalities and advertising requires that the empirical model be specified as a two equation model. The first equation is probability of a highway fatality equation and the second equation is a demand for advertising equation.

The demand for alcohol, by an individual, shortly before or while driving $\left(q^{*}\right)$ is defined as a function of alcohol price $(P)$, alcohol advertising $(A)$, and other variables affecting alcohol demand such as income, availability of alcohol, alcohol sentiment and other taste variables ( $x$ ).

$$
q^{*}=q(P, A, x)
$$

The probability of a fatal motor vehicle accident $(\rho)$ is defined as a function of an individual's alcohol consumption shortly before or while driving and a vector of additional variables affecting the probability of a fatal motor vehicle accident $(y)$.

$$
\rho=\rho\left(q^{*}, y\right)
$$


Substitution of the alcohol demand equation $1-1$ into the probability of a motor vehicle fatality equation 1-2, and aggregating across individuals, yields a reduced form probability equation.'

$$
\rho=\rho(\mathrm{P}, \mathrm{A}, \mathrm{x}, \mathrm{y})
$$

The second equation in the empirical model is the advertising demand function. The theoretical static oligopoly model of advertising and consumption developed by Schmalensee (1972) provides some important insights in specifying the advertising demand function. This theoretical model assumes that firms tend to compete with advertising rather than price which tends to occur in the alcohol industry. It is assumed that price is set by total industry output and each firm takes the price as exogenous. In this model, both demand for the firms's output and its costs are functions of its advertising. The advertising demand function is derived by differentiating the profit function with respect to advertising. Rearranging terms and aggregating to the industry level yields:

$$
A=A(r, Q, P, M C)
$$

Equation 1-4 shows that industry advertising is a function of the price of advertising ( $r$ ), industry sales $(\mathrm{Q})$, the price of alcohol and the marginal cost of producing alcohol $(\mathrm{MC})$. In equation $1-2 \rho$ is a function of $q^{*}$, which means that $q^{*}$ is a function of $\rho$ and $y$, which also implies that $Q$ is a function of $\rho$ and $y$. This function can replace $Q$ in equation $1-4$ which results in equation $1-5$.

$$
A=A(r, \rho, P, y, M C)
$$

9 The industry level response function described in section 2.1 imposes some limits on the functional relationship described in equations 1-1 and 1-3. In equation 1-1, the effect of $A$ on $q^{*}$ is positive but subject to decreasing marginal product. A logistic transformation of $q^{*}$ in $1-1$ can provide this relationship. A logistic transformation of $q^{*}$ would then appear in equation $1-2$ and be replaced by a linear advertising variable in equation 1-3. 
Equation $1-5$ shows that industry level advertising is a function of the price of advertising, $r$, the fatality rate, $\rho$, the product price, $\mathrm{P}$, variables affecting the probability of a fatal motor vehicle accident, $y$ and the marginal cost of alcohol production, MC. Equations 1-3 and 1-5 are a quasi-structural model of alcohol advertising and motor vehicle fatalities and can be estimated by Two Stage Least Squares.

\section{The Data Set}

The unit of observation in this data set is an aggregation of counties known as an Area of Dominate Influence (ADI). The Arbitron Company (1990) has defined the ADI for all television markets in the United States. The ADI is a well known concept in commercial advertising research and consists of the counties within the reach of a group of television transmitters. The original ADI definitions were established in 1965, and are updated annually. The ADI is similar to, but somewhat larger than, a Metropolitan Statistical Area. ${ }^{10}$ The data set consist of quarterly observations, from 1986 to 1989 , for the top 75 ADIs the United States and includes 1200 observations." These 75 television markets account for more than 75 percent of the total population. Means and summary definitions of all variables are found in

${ }^{10}$ Arbitron assigns each county to only one ADI. This is only an issue for the counties between the Baltimore and Washington DC ADIs. Arbitron assigned the following Maryland counties to the Washington DC ADI: Allegany, Calvert, Charles, Fredrick, Montgomery, Prince Georges, and St. Marys. Since people in these counties are exposed to some advertising from Baltimore, there may be some under estimation of advertising exposure in the Washington DC ADI.

"Over the four years covered by the data set there were three changes in the list of top 75 markets. However, the data set uses the set of 75 markets that were the top 75 in 1988 for all four years. There were also some minor changes in the set of counties included in some ADls over the four years. These changes have been included in the aggregation and computation of all $\mathrm{ADI}$ level data. 


\section{Tajle 1.}

\section{4.! Fatalities Rates}

Motor vehicle fatality rates are the best empirical measures of drunk driving available." While not all motor vehicle fatalities are the result of drunk driving, there is a strong correlation between the two measures. The fatalities data was taken from the National Highway Traffic Sarety Administration's (NHTSA) Fatal Accident Reporting System. The Fatal Accident Reporting System contains data on all fatal accidents in the US and includes the county of occurrence and date of the accident. The population data was taken from the U.S. Department oi Commerce, Bureau of Health Professions. Area Resource File. The Area Resource File contains data on population, by age, and by county of residence. Since the county level population is reported for 1980 and 1984 only, quarterly population for 1986 though 1989 was derived by extrapolation. ${ }^{13}$ Eight fatality rates based on age and time of the accident are used to measure drunk driving.

The first fatality rate includes all ages and is called the total fatality rate. This rate ircludes the largest percentage of non-alcohol related fatalities. The three additional age specific factality rates focus on the effects of alcohol advertising and motor vehicle fatalities of younger pzople. These age specific fatality rates are for ages 18 to 20,21 to 24 , and 25 to 34 . Alcohol involvement in motor vehicle accidents is estimated to be much higher in the younger age groups

${ }^{12}$ Fatality data is preferred to accident data due to the across state variability in reporting standards for accident data.

${ }^{13}$ The ARF file population data is reported by age intervals which include 15 to 19 and 20 to 24. Because of the minimum drinking age law, the age intervals of 18 to 20 and 21 to 24 are more appropriate. The ARF data was adjusted based on state age specific population data to ieflect the alternative age breakdowns. 
than it is in the overall population. Also, Atkin (1987) concludes that younger age groups are more sensitive to alcohol advertising. It is, therefore, important to examine the effects of alcohol advertising on motor vehicle fatalities for three younger age groups as distinct from the overall population.

To focus on alcohol involvement in motor vehicle fatalities four additional fatality rates are defined. These four additional fatality rates are defined exactly as the first four are defined with the exception that the fatality occurred between 12:00 a.m. and 3:59 a.m. These fatality rates are called night fatality rates. The NHTSA estimates that a significantly higher percentage of these fatalities are alcohol involved than fatality rates that include all hours.

The fatality equation is specified as a logistic equation. The logistic functional form is ideal since it constrains the fatality rate to lie between zero and one. The logistic specification is obtained by transforming the fatality rate to $\ln [M /(1-M)]$, where $M$ is the fatality rate and $\ln$ is the natural logarithm. Maddala (1983) shows that weighted least squares should be used with this logistic transformation. The weight is $[n M(1-M)]^{t}$, where $n$ is the relevant $A D I$ population.

\subsection{Advertising Data}

Two companies, The Arbitron Company and LNA (Leading National Advertisers) collect advertising data for all the major media. The Arbitron Company collects data for broadcast and cable television advertising and LNA collects data for radio, print, and outdoor advertising.

These two companies are widely recognized in the advertising industry as the primary source of advertising data. All of the data reported by Arbitron and LNA are independent estimates and do not use any intormation from alcohol producers. Arbitron's estimates are derived from 
monitoring each media and estimating per unit costs of advertising. LNA's estimates are derived from monitoring specific media or from advertising wholesaler's reports. In 1990 the total expenditure on alcohol advertising was 1.04 billion dollars for the media tracked by Arbitron and LNA. Table 2 summarizes the distribution of these expenditures.

Television advertising consists of network, syndicated, and spot advertising. Table 2 shows that network and syndicated television advertising accounts for 33 percent of all alcohol advertising expenditures. However, network and syndicated advertising are done nationally and have no cross sectional variation. Spot advertising accounts for 20 percent of all alcohol advertising expenditures. Spot advertising is done locally and thus varies in each ADI.

Radio advertising also consists of borh network and spot advertising. Again, network radio advertising is national and spot radio is local. Network radio advertising of alcohol is trivial and spot radio accounts for 7 percent of alcohol advertising. Spirits advertising is, of course, banned from television and radio in the United States.

Table 2 shows that magazine advertising accounts for 27 percent of all alcohol advertising and is primarily spirits advertising. LNA collects data for 166 magazines This advertising is both national and regional. That is, some advertisements, in national magazines, differ by region. Regions can include any number of urban areas, states or combinations of the two. Magazine advertising was classified as national since the local variation is limited.

The remaining media reported by Arbitron and LNA are outdoor, cable, and newspapers. Outdoor advertising expenditures are reported to LNA by over 200 wholesalers in all ADIs that permit outdoor alcohol advertising. Table 2 shows that outdoor advertising represents five percent of all alcohol advertising. Outdoor advertising varies by location. Arbitron continuously 
monitors six cable networks. This programming is shown nationally and has no local variation. Local cable is not monitored. Table 2 shows that cable advertising represents four percent of al alcohol advertising. LNA measures daily and Sunday newspaper alcohol advertising space and projects expenditures for the top 36 and 125 ADIs, respectively. Table 2 shows that this advertising represents three percent of all alcohol advertising.

In this daca set, the media used to measure alcohol advertising are spot television. spot radio, and outdoor. These media represent 91 percent of all expenditure with local origin. The remaining nine percent is newspaper advertising. Spot television advertising data consists of number of minutes, number of advertisements and dollar expenditures on beer and wine advertising. These data are reported by quarter and by ADI. Arbitron records all programming from all television stations in the top 75 ADIs. These tapes are edited and a log of all commercial activity is created. Advertising expenditures are estimated using prices based on station ratings, data from the stations, and data from advertising agencies. The top $16 \mathrm{ADIs}$ are monitored continuously and the remaining 59 ADIs are sampled one random week per month. Spot radio data and outdoor data are reported to LNA by advertising wholesaler organizations. For both media, these data are advertising expenditures, by ADI, and include brand detail.

The data that is actually available are seconds of spot TV advertising, spot TV prices, spot radio expenditures, and outdoor expenditures. Advertising could be measured with either advertising expenditures or advertising messages. Messages have the advantage of not being dependent on local advertising prices. To define a message variable it is necessary to convert radio messages and outdoor messages to a TV equivalent message. This conversion can be done by assuming that the relative price of a message in each media is equal to relative expected 
number of people exposed to the message. Let:

$A_{\mathrm{v}}=t \mathrm{v}$ advertising in seconds

$A_{r}=$ radio advertising in seconds

$A_{b}=$ outdoor advertising in number of locations per time unit

$\mathrm{P}_{\mathrm{Nv}}=$ price per second of tv advertising

$P_{r}=$ price per second of radio advertising

$P_{b}=$ price per outdoor location per time unit

and let $\mathrm{P}_{\mathrm{v}}=\theta_{\mathrm{r}} \mathrm{P}_{\mathrm{r}}$ and $\mathrm{P}_{\mathrm{n}}=\theta_{\mathrm{b}} \mathrm{P}_{\mathrm{b}}$ where $\theta_{\mathrm{r}}$ measures the impact of a second of $\mathrm{TV}$ time relative to a second of radio time. Effective radio messages are $A_{r} / \theta_{r}$. The variable $\theta_{b}$ measures the impact of a second of TV sime relative to an outdoor location per unit time. Effective outdoor messages are $A_{b} / \theta_{b}$. If $A$ measure total effective messages then, $A=A_{t v}+A_{r} / \theta_{r}+$ $A_{b} / \theta_{b}$. Since $A_{w}$ can be multiplied by $P_{w} / P_{w}$, and $1 / \theta_{v}$ replaced by $P_{v} / P_{w}$ and $1 / \theta_{b}$ replaced by $P_{b} / P_{w}$, then $A=A_{v} P_{w}+A_{r} P_{s} / P_{w}+A_{b} P_{b} / P_{w}$.

\subsection{Alcohol Price}

The alcohol price was computed with data from the American Chamber of Commerce Research Association (ACCRA). These price data are reported on a quarterly basis for over 200 cities and towns in the United States. In cases where the ACCRA reports a price for more than one community within a ADI, the prices were simply averaged. If an ADI had missing data, the price data were estimated by interpolation between the available quarters. ${ }^{14}$ The ACCRA data are for specific brands of beer, wine and spirits and excludes sales taxes and deposits. The beer price data is for a six-pack of 12 ounce containers of Schlitz or Budweiser. The wine price

${ }^{14} \mathrm{~A}$ few of the $75 \mathrm{ADI}$ were not reported at all, or were seldom reported, by the ACCRA. In these cases a nearby metropolitan area, in the same state, with similar characteristics was used as a proxy. The missing ADIs are Rochester NY, Providence RI, Flint MI, Little Rock AK, Grand Rapids MI, and Detroit MI. 
data is for a 1.5 liter bottle of Paul Masson Chablis. The spirits price data was the price of a $750 \mathrm{ml}$ bottle of Seagram's 7-Crown until the fourth quarter of 1988 when it switched to the price of a one litter bottle of J\&B Scotch. To keep the series consistent, first the price of J\&B was multiplied by .75 to adjustment for container size. Next, the ratio of the price of Seagram's 7-Crown to the price of $\mathrm{B} B \mathrm{~B}$ was computed, for each $\mathrm{ADI}$, using data from the third and fourth quarter of 1988 . The J\&B price was divided by this ratio to project the price of Seagram's 7 Crown.

The alcohol price variable is a weighted average of the price of a unit of pure alcohol for each of the three beverages. To convert to price per liter the beer price was divided by 2.56 , the wine price was divided by 1.5 and the spirits price was divided by .75 . Next, to convert the price per liter to a price per liter of pure alcohol the beer price was multiplied by .04 , the wine price was multiplied by .11 , and the spirits price was multiplied by .41 . The weighted average price was constructed using weights of $.536, .137$ and .327 , for beer, wine and spirits respectively. These weights represent the proportion of total alcohol consumed in each of the three beverages. The alcohol percent and consumption weights are for 1986 and were taken from the Brewers Association of Canada's International Survey of Alcoholic Beverage Taxation and Control Policies. The same weights are used for all 16 quarters in the data set.

\subsection{Consumer Price Index}

All variables measured in dollar terms are adjusted for $\mathrm{ADI}$ and temporal price level changes. Adjustment for cross sectional price level differences is more important when using ADI level data than when using state level data. Price level differences tend to be related to ADI size. State level data tends to average out ADIs of different sizes and thus there is more 
between ADI price level variation than interstate price level variation. The consumer price index used in this study was computed using the monthly national CPI for all urban consumers reported in Business Conditions Digest, which is published by the Bureau of Economic Analysis, US Department of Commerce, and the local price index reported by the ACCRA. The monthly CPI was averaged together to create a quarterly CPI for the US and adjusted such that the first quarter of 1986 is the base period. The ACCRA reports a quarterly cost of living index for over 200 cities and towns in the US. The ACCRA cost of living index is based on over sixty categories of consumer purchases and uses expenditure weights based on government survey data of expenditures of mid-management households. The ACCRA cost of living index has no time variation. The cost of living index used in this study was computed by multiplying the ACCRA index for each quarter by the national $\mathrm{CPI}$ for each quarter.

\subsection{Other Independent Variables ${ }^{15}$}

Real per capita personal income is also included in all estimated equations. County level data on nominal income were taken from the Area Resource File. ${ }^{16}$ Population weights were used to create an ADl level income variable. This variable should be positively related to the demand for alcohol, as well as to the demand for health and the quality and condition of motor vehicles. Thus, the predicted effect of income on fatality rates is ambiguous.

is State data is difficult to use since a number of ADIs cross state boundaries. Data for the cross state ADI's would have to be constructed as population weighted aggregates of the states included in the ADI.

${ }^{16}$ The growth rate of income for each ADI between 1987 and 1988 was computed and this rate was used to project 1989 income by ADI. This is a good estimate since, on a national level, the rate of growth in per capita disposable income from 1987 to 1988 was $3 \%$ and from 1988 to 1989 was $3.3 \%$. 
The median years of schooling, by county, for persons 25 or older was taken from the Area Resource File. This variable was included since it may be correlated with health education. The data was available on a county level only for 1970 and 1980 . Data for the sample period was estimated by linear extrapolation.

The unemployment rate, by county, for persons 16 or older was taken from the Area Resource File. This variable was included since it may be correlated with stress related alcohol consumption or with income. The data was available on a county level, on an annual basis for each of the sample years. Data for the quarterly periods were estimated by interpolation.

Also included are two demographic variables. These are the percentage of the ADI population that is black and the percent of the ADI population that is Hispanic. These variables were computed using population data from the Area Resource file. They are included because they capture any ethnic differences in drinking and driving practices.

A set of variables measuring religious adherence are used in several fatality regressions. Adherents are defined as individuals that participate regularly in the activities of their sect. The four religion variables that are included are the percent of the ADI population that are adherents in the Mormon Church, Southern Baptist Church, Catholic Church, and other Christian and Jewish religions. These variables are included since individuals that choose to be active in their religious sect probably also choose a more temperate lifestyle than non-adherents. The Mormon and Southern Baptists Churches specifically discourage alcohol consumption. The data come from Churches and Church Membership in the United States, 1990 and 1980, published by the Glenmary Research Center. The Glenmary Research Center estimated the number of religious adherents, by county for 133 separate sects. The 1980 data and 1990 data were used to 
construct a quarterly growth rate which was then used to estimate the number of adherents by quarter. These estimates were aggregate to the ADI level and divided by the ADI population. A set of dummy variables which measure the size of the ADI and a variable which measures the percent of the population residing in urban communities have been defined. These variables were included because larger and denser cities have lower average driving speeds which leads to less fatality associated with motor vehicle accidents. The dummy variables were compured using population data from the Area Resource file. The variable called Large City is equal to one if the ADI is over 5 million people and the variable called Medium City is equal to one if the ADI is less than 5 million and greater than 1.3 million people. The excluded third variable is ADIs less than or equal to 1.3 million people. The Percent Urban variable is the percent of each county that is living in incorporated communities of over 2500 people or living in unincorporated communities of over 50,000 people. These percentages were aggregated to the county level using population weights.

The advertising demand function includes two variables which control for market size. These are the number of TV stations, from Arbitron, and the number of radio stations, from the World Radio Handbook, in each ADI. These which are included since more stations will result in more messages in each ADI. The advertising demand curves also include the price of spot television advertising which comes from Arbitron.

Also included in a number of regressions are a set of 9 regional dummy variables. The 9 regions are regions used by the Census. These dummies are equal to 1 if an ADI is in the region and otherwise is zero. These regional dummies can control for regional variations that are otherwise unobserved. 
Finally, the time dummies are included in the regressions as controls for temporal variation in unmeasured variables and other time trends. The time dummies are a set of 15 dichotomous variables for each of the quarters from second quarter 1986 through the last quarter of 1989 . The time dummies are included in all regressions.

\section{Regression Models}

The first empirical problem is the potential endogeneity between advertising and motor vehicle fatality. This possibility is examined with a Wu-Hausman test for correlation between the error terms in the fatality equation and the advertising equation. Advertising cannot be treated as exogenous if these error terms are correlated. This test can be performed by first regressing advertising on all the exogenous variables in the structural model and saving the predicted value from this regression. Next, fatality is regressed on all exogenous determinants of fatalities, alcohol advertising, and predicted alcohol advertising. The null hypothesis is that the coefficient on the predicted advertising variable is equal to zero. Advertising cannot be treated as exogenous if the null hypothesis is rejected. The test was performed for the fatality rate defined for all ages. The predicted value of advertising was significant at the one percent level. The null hypothesis of exogeneity is, therefore, rejected and advertising and fatalities are treated as endogenous.

Tables 3 through 6 present the results from Two Stage Least Squares estimation of 16 alternative specifications of the motor vehicle fatality equation. The columns in each table represent alternative age definitions of the fatality rate. These four tables are arranged as two sets of two tables. Tables 3 and 5 present the results from regressions using fatality rates defined over all hours and tables 4 and 6 present the results from regressions for night fatality 
rates. The regressions in tables 3 and 4 include independent variables which measure economic and demographic conditions and are called demographic variable models. The regressions in cables 5 and 6 include only the endogenous advertising variable, alcohol price, city size dummies, regional dummy variables and time dummies. The regional dummies are included to control factors which vary by region such as highway conditions. These models are called Fixed Effects models and are estimated as a test of robustness with respect to variable specification.

The regression results provide evidence that alcohol advertising increases motor vehicle fatalities. The endogenous advertising variable is positive in all 16 regressions and significant at the 5 percent level in 13 regressions. The advertising variable is also marginally significant in the other three regressions. In the age specific regressions, the magnitude of the advertising coefficients increase with age. These age specific results seem to suggest that for people under 35, the effects of alcohol advertising on moror vehicle fatalities may cumulate with age. This may reflect both a sensitivity to alcohol advertising and access to a motor vehicle. The magnitude of the advertising coefficients are larger in the night mortality regressions than in the all hours regressions. This reflects the greater degree of alcohol involvement in night mortalities. The magnitudes of the advertising coefficients in the Fixed Effects models are smaller than the corresponding regressions in the Demographic models. This may reflect the fact that the dummies in Fixed effects models account for all cross sectional only, and time only variation in the dependent variable. This leaves only the variance in the dependent variable which is both cross sectional and time varying to be explained by an independent regressor such as advertising.

The elasticity of motor vehicle fatalities with respect to advertising is $\beta^{*} A_{1}$, where $\beta$ is 
the alcohol advertising variable coefficient and $A_{1}$ is the mean of the advertising variable. Using the All Age regressions in tables 3 and 5 this calculation results in an elasticities of -.11 and .06 , respectively.

In tables 3 to 6 alcohol price is generally negative and significant. The price of alcohol is the consumption weighted average of the price of the three component beverages. The weighted average price of alcohol is a good empirical variable since it represents all three beverages but does not create the collinearity problems that occur when all three beverage prices are entered separately. This variable only represents the money price of alcohol. The full price of alcohol also includes search costs which are of particular importance to people under the legal drinking age.

The regression results can be used to estimate the elasticity of motor vehicle fatalities with respect to beer taxes. Using the results in for the all age regressions in tables 3 and 5 , the elasticity of motor vehicle fatalities with respect to the price of pure alcohol is between .19 and .15. These elasticities can be used to approximate the elasticity of motor vehicle fatalities with respect to beer taxes. Since the beer cax is about 20 percent of the purchase price of beer, the tax on alcohol in beer is also about 20 percent of the purchase price of alcohol in beer. The elasticity of motor vehicle fatalities with respect to beer taxes is thus about .04 to .03 . This value is similar to those found in other studies (i.e. Chaloupka, Saffer, and Grossman, 1993) involving beer taxes and motor vehicle fatalities. For a given percentage change, alcohol price has a bigger impact than alcohol advertising on motor vehicle fatalities.

Since both health and alcohol are normal goods, the effect of income on alcohol demand is uncertain. However, in tables 3 and 4 , real income is general negative and significant. This 
suggests that the impact of income on health exceeds that of income on alcohol consumption and drunk driving. This result is consistent with other studies (i.e. Chaloupka, Saffer, and Grossman, 1993) of motor vehicle fatalities using state level data.

In tables 3 and 4 , the religion variables, Percent Mormon, Percent Southern Baptist, Percent Catholic, and Percent other religions are all generally negative and significant. These relationships are the weakest for Southern Baptists and the 18-20 year old group. This suggests that the Southern Baptist prohibition against drinking may lead to less public drinking and more private drinking, such as in cars. The 18-20 year old group may be least influenced by the religious prescriptions of their elders.

The ADI size variables, Medium City and Large City and Percent Urban are proxies for highway conditions. Larger cities generally have more traffic congestion which reduces average speeds and reduces the probability of a fatal motor vehicle accident. The size variables are negative and significant in all specifications for both the Demographic Models and the Fixed Effects Models. The percent urban is only included in the Demographic Models and is negative and significant in six of the eight regressions. The coefficient of the Large City variable is always larger. in absolute value, than the Medium City coefficient. These results support the theory that density increases traffic congestion which reduces speed which reduces motor vehicle facalities.

Schooling may be a proxy for health knowledge which would have a positive effect on the demand for health. An increase in the demand for health would reduce the demand for alcohol and reduce the motor vehicle mortality rate. Schooling is negative and significant in all specifications which confirms this expectation. 
Both minority variables are generally significant but of opposite signs. The percent Black is negative and the percent Hispanic is positive. These results may indicate an important cultural distinction in drinking and driving behavior between the two groups.

The unemployment rate is generally negative and marginally significant. Unemployment could increase mortality if it resulted in more drinking due to stress or more leisure time. Alternatively unemployment could reduce fatalities if it resulted in less drinking away from home. The negative effect apparently indicates that the unemployed either drink less or at least drink at home.

The time dummies are included in both the Demographic Models and the Fixed Effects Models and are almost always significant and positive. They show a time pattern of higher fatalities in the third and fourth quarters with the lowest fatalities in the first quarter. This parallels the time pattern of alcohol consumption and lags the pattern of alcohol advertising by one quarter. ${ }^{17}$

Table 7 presents the results from two reduced form highway fatality models and two reduced form advertising models. The logistic highway fatality rate used is based on fatalities for all ages and all times of the day fatality rate. All four equations are estimated with OLS using the weight derived for the above logistic fatality rate. These models are included to

\footnotetext{
${ }^{17}$ Because of this lag pattern, a lag specifications of all the models were also estimated. In these specifications, advertising was lagged one quarter, and all observations for first quarter of 1986 were dropped. In these models current mortality was regressed on current values of all variables except advertising, which was from the prior quarter. The results from these models are not reported since they were almost identical to the results that are reported.
} 
estimate the effect of the price of advertising on highway fatalities and advertising. ${ }^{\text {Is }}$ The first and third model in table 7 use the Demographic model variables while the second and third models also use the regional dummies from the Fixed effects models. The overall results in Table 7 conform to expectations. The price of advertising is negative and significant in all specifications. The elasticity of highway fatalities with respect to the advertising price is about .05 and own price elasticity of advertising is about .27 .

\section{Conclusions}

Based on the regression results, alcohol advertising is found to be a contributing factor in the high level of motor vehicle fatalities in the United States. While advertising is significant, it is less imporcant than alcohol price as a determinant of motor vehicle fatalities. Using two stage least squares, both Demographic and Fixed Effects Models were estimated. Reduced form advertising demand models were also estimated. These models show that the demand for advertising is negatively related to the price of advertising.

The likely effects of two advertising policy initiatives designed to limit alcohol advertising can be estimated using the data and econometric results. The first policy is an extension of the voluntary ban on broadcast advertising to include beer and wine. ${ }^{19}$ The

13 The theoretical advertising equation includes variables measuring the marginal cost of alcohol production and variables other than alcohol which affect highway fatality rates. The marginal cost of alcohol production can be assumed constant across the country and thus falls in the intercept. The other variables which affect highway fatalities are proxied by the included variables. An omitted variable bias would exist to the extent that the included variables do not act as good proxies.

is The effect of a large reduction in advertising must account for the non-linearity of the functional form. To estimate this effect first subtract the logistic fatality equation with advertising at level $A_{0}$ from the logistic fatality equation with advertising at level $A_{1}$. Advertising level $A_{1}$ is the mean level of advertising in the data set and $A_{0}$ is a much smaller 
second policy is the elimination of the tax deductibility of all alcohol advertising expenses.

A ban on broadcast advertising of beer and wine is probably the most discussed option for reducing alcohol advertising. The coefficients from the all age regressions in table 3 and table 5 can be used to compute the elasticity of highway fatalities with respect to advertising. Since these elasticities were estimated with spot data, it is assumed that the effect of national advertising on fatalities is the same. These elasticities can be used to estimate an upper bound effect of banning alcohol advertising. The estimated effect is an upper bound because these elasticities assume no substitution to other media. The sum of local and national broadcast advertising is about 200 percent of the advertising represented by the advertising variable. The elasticity predicts that a complete ban on broadcast alcohol advertising could save about 10,000 to 5,000 lives per year. ${ }^{20}$ As lower bound, if a ban on broadcast advertising resulted in complete substitution to other media and no reduction in the marginal product of advertising in other media, then the ban would have no effect at all.

An estimate of the amount of media substitution that might follow a ban on beer and wine broadcast advertising would help narrow the range between the upper and lower bound estimates. Since broadcast advertising for spirits is banned while broadcast advertising of beer and wine is not banned, it is possible to estimate the effect of the spirits ban on total spirits

level. Taking the anti-log of both sides, the elasticity is $\left(A_{1} / A_{0}\right)^{3}-1$.

20 Saffer (1991) estimates the effect of a ban on beer and wine broadcast advertising on highway fatalities using international data. The research concludes that a ban on beer and wine advertising could reduce highway fatalities by about 23 percent which would be about 10,000 lives in the US. This estimare implicitly assumes no media substitution. 
advertising. This estimation is based on two assumptions. First, a number of researchers agree that for mature products, advertising expenditures are a fixed percent of sales revenue. The second assumption is that this percentage is for beer and wine about the same as for spirits. Under these assumptions, the ratio of advertising expenditures on beer and wine advertising to advertising expenditures on spirits would be about the same as the ratio of consumer expenditures on beer and wine to consumer expenditures on spirits. In the United States, total expenditures on beer and wine are about 3 times the expenditures on spirits. ${ }^{21}$ Table 2 shows that the advertising expenditures on beer and wine are also about 3 times advertising expenditures on spirits. This suggests that the level of spirits advertising is about what would be expected if spirits advertisers were allowed to use broadcast media. Since spirits producers have substituted other media, it is likely that if beer and wine producers were banned from broadcast media, they would also substitute other media.

An extension of a broadcast ban to include a ban in all media would eliminate media substitution. The Brewer's Association of Canada's international survey of 23 countries reports that about half the countries that ban TV advertising of beer, wine or spirits have not extended the ban to all media. This survey data suggests that a complete media ban might be difficult to legislate. Even if a complete media ban were passed, it would not exclude other types of marketing. Other types of marketing include sports and cultural event sponsorships, consumer novelties, in-store displays, clothing with brand names, closed circuit television in public places. product placements, and direct marketing. It might be very difficult to legislate against all forms

${ }^{21}$ Data is from Alcoholic Beverages Taxation and Control Polices, 8th edition, published by the Brewers Association of Canada (1992). 
of marketing.

These arguments suggest that if a ban on broadcast advertising of beer and wine were enacted it would not include other media and would result in considerable substitution to other media. However, the concentration of a given advertising budget into less media will reduce the average product of aggregate advertising. Also a broadcast advertising ban could reduce consumption by signaling a collective concern about potential adverse consequences of alcohol. The implication of these arguments is that the effect of a ban would be closer to the lower bound estimate of no effect than to the upper bound estimate of 5,000 to 10,000 lives. This could put the effect of a ban on only broadcast alcohol advertising in the range of 2000 to 3000 lives saved per year.

The elimination of alcohol advertising as a cost which reduces taxable corporate income is another policy option. ${ }^{22}$ Since the corporate income tax rate is 46 percent, elimination of the tax deductibility of alcohol advertising costs would raise the price of advertising by about 100 percent. Since the elasticity of highway fatalities with respect to the price of advertising is .05 , a 100 percent increase in the price of advertising would reduce fatalities by about 2300 per year. Elimination of the tax deductibility of alcohol advertising would also result in new tax revenue. Since the alcohol advertising price elasticity is about .27 , a 100 percent increase in price would reduce alcohol advertising by about 27 percent. Total alcohol advertising would be reduced from about $\$ 1$ billion per year to about $\$ 730$ million per year. The new taxes which

22 Industry concern that this option might be enacted has resulted in creation of the Advertising Tax Coalition and the State Advertising Coalition. In 1992 these organizations helped to defeat an amendment in the US House of Representatives and 14 state initiatives to tax advertising. 
would be paid if this $\$ 730$ million was not allow as a cost would be about $\$ 336$ million per year. 


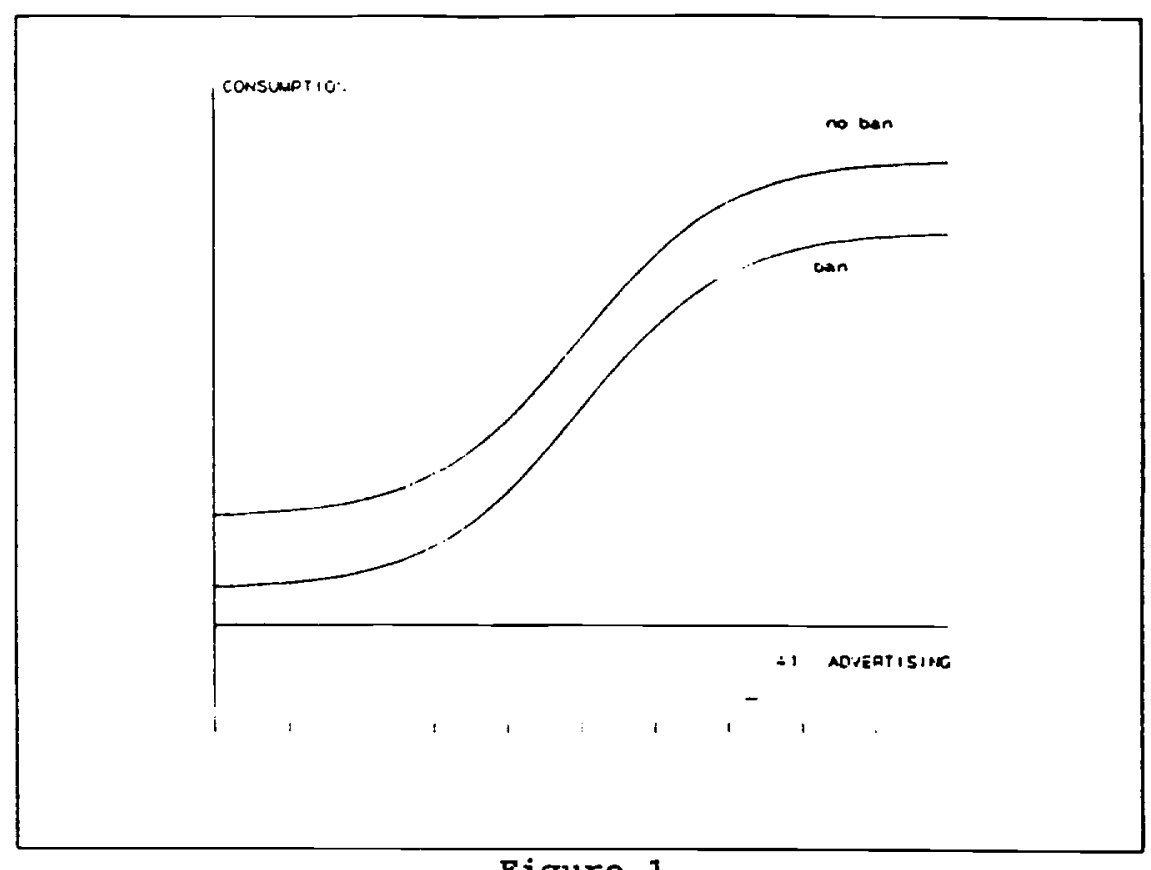

Figure 1

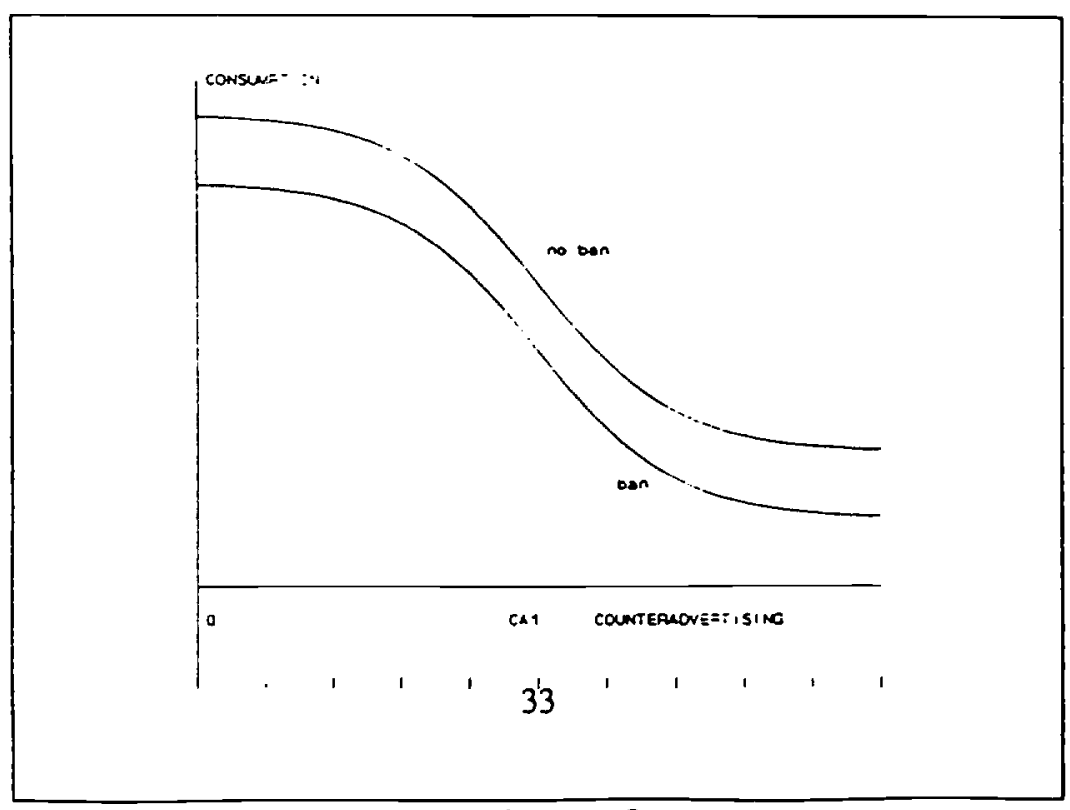

Figure 2 
Table 1

Definitions and Means of Variables

\begin{tabular}{|c|c|}
\hline Total Fatalities Rate & $\begin{array}{l}\text { Motor vehicle fatalities, for all occupants, divided by population. This } \\
\text { variable is defined for all ages, ages } 18 \text { to } 20 \text {, ages } 21 \text { to } 24 \text {, and } \\
\text { ages } 25 \text { to } 34 \text {. The mean fatality rates for each group are, } \\
\text { respectively, } \mu=.00005, \mu=.00012, \mu=.00010, \mu=.00006\end{array}$ \\
\hline Advertising & $\begin{array}{l}\text { Sum of alcohol advertising for spot tv, spot radio, and outdoor in tv } \\
\text { equivalent message units. } \mu=48,126.22\end{array}$ \\
\hline Alcohol Price & $\begin{array}{l}\text { Weighted average price of a unit of alcohol in beer, wine and spirits. } \\
\text { Weights are percentage consumption of alcohol in the three } \\
\text { beverages. Price is divided by ADI specific CPI. } \mu=110.47\end{array}$ \\
\hline Real Income & $\begin{array}{l}\text { Personal income for the counties in the ADI. Income is weighted by } \\
\text { the percent of the ADI the county population represents. Income is } \\
\text { divided by the ADI specific CPI. } \mu=14674.23\end{array}$ \\
\hline Medium City & $\begin{array}{l}\text { ADI with populations greater than } 1.3 \text { million and less than or equal } \\
\text { to } 5 \text { million. } \mu=.57\end{array}$ \\
\hline Large City & ADI with over 5 million population. $\mu=.08$ \\
\hline Schooling & Median years of schooling for persons over $25 . \mu=12.3$ \\
\hline Unemployment Rate & $\begin{array}{l}\text { The unemployment rate for the civilian labor force aged } 16 \text { or older. } \\
\text { Data are reported as a percentage times } 10 . \mu=59.81\end{array}$ \\
\hline Percent Catholic & Percent of the ADI that are Catholic. $\mu=18.23$ \\
\hline Percent Mormon & Percent of the ADI that are Mormon. $\mu=1.56$ \\
\hline $\begin{array}{l}\text { Percent Southern } \\
\text { Baptist }\end{array}$ & Percent of the ADI that are Southern Baptists. $\mu=8.42$ \\
\hline $\begin{array}{l}\text { Percent Other } \\
\text { Adherents }\end{array}$ & $\begin{array}{l}\text { Percent of the ADI that are adherents of religions other than Catholic, } \\
\text { Mormon or Southern Baptist. } \mu=24.19\end{array}$ \\
\hline Percent Urban & $\begin{array}{l}\text { The percent of the ADI population that lives in towns of at least } 2500 \\
\text { people or in areas contiguous to cities of at least } 50,000 \text { people. } \\
\mu=72.16\end{array}$ \\
\hline Percent Black & Percent of ADI that self-identify as Black. $\mu=11.36$ \\
\hline Percent Hispanic & Percent of ADI that self-identify as Hispanic. $\mu=6.31$ \\
\hline Advertising Price & $\begin{array}{l}\text { Weighted average real price of alcohol advertising on TV, radio and } \\
\text { outdoor media. } \mu=17.51\end{array}$ \\
\hline TV Stations & Number of TV Stations in each ADI. $\mu=4.57$ \\
\hline Radio Stations & Number of Radio Stations in each ADI. $\mu=38.3$ \\
\hline
\end{tabular}

- Data is for the top 75 ADIs (metropolitan areas) in the United States for the first quarter 1986 to the last quarter of 1989. 
Table 2

Advertising Expenditure in Millions of Dollars by Media and Beverage $1990^{\circ}$

\begin{tabular}{|c|c|c|c|c|c|c|}
\hline & $\begin{array}{l}\text { Beer and } \\
\text { Wine }\end{array}$ & Spirits & $\begin{array}{l}\text { Total } \\
\text { Alcohol }\end{array}$ & $\begin{array}{l}\text { As \% of } \\
\text { National } \\
\text { Media }\end{array}$ & $\begin{array}{l}\text { As \% of } \\
\text { Local } \\
\text { Media }\end{array}$ & $\begin{array}{l}\text { As \% } \\
\text { of all } \\
\text { Media }\end{array}$ \\
\hline $\begin{array}{l}\text { Network and } \\
\text { Syndicated TV }\end{array}$ & 347.30 & & 347.30 & .52 & & .33 \\
\hline Cable & 37.00 & & 37.00 & .06 & & .04 \\
\hline Network Radio & 5.00 & & 5.00 & .01 & & 0 \\
\hline Magazines & 45.60 & 232.20 & 277.80 & .42 & & .27 \\
\hline $\begin{array}{l}\text { Total National } \\
\text { Media }\end{array}$ & 434.9 & 232.20 & 667.10 & 1.00 & & .64 \\
\hline Spot TV & 210.40 & 1.30 & 211.70 & & .56 & .20 \\
\hline Spot Radio & 72.40 & 2.00 & 74.40 & & .20 & .07 \\
\hline Outdoor & 20.00 & 36.50 & 56.50 & & .15 & .05 \\
\hline Newspapers & 13.90 & 18.90 & 32.80 & & .09 & .03 \\
\hline $\begin{array}{l}\text { Total Local } \\
\text { Media }\end{array}$ & 316.70 & 58.70 & 375.40 & & 1.00 & .36 \\
\hline $\begin{array}{l}\text { Total of All } \\
\text { Media }\end{array}$ & 751.70 & 290.90 & 1042.60 & & & \\
\hline & & & & & & \\
\hline
\end{tabular}

- Source: LNA 1991 
Table 3

All Fatality

Demographic Models

\begin{tabular}{|c|c|c|c|c|}
\hline & AII AgES & Age 181020 & XgE 21 1024 & Age 2510 34 \\
\hline Intercept & $\begin{array}{l}-6.051 \\
(13.27)\end{array}$ & $\begin{array}{l}-5.634 \\
(0.74)\end{array}$ & $\begin{array}{l}-3.765 \\
(5.05)\end{array}$ & $\begin{array}{l}-3.427 \\
(5.33)\end{array}$ \\
\hline Advertising & $\begin{array}{l}0.0000023 \\
(5.52)\end{array}$ & $\begin{array}{l}0.0000024 \\
(3.53)\end{array}$ & $\begin{array}{l}0.0000031 \\
(4.61)\end{array}$ & $\begin{array}{l}0.0000033 \\
(5.56)\end{array}$ \\
\hline Alcohol Price & $\begin{array}{l}-0.0018 \\
(2.43)\end{array}$ & $\begin{array}{l}-0.00033 \\
(0.30)\end{array}$ & $\begin{array}{l}-0.003 \\
(2.57)\end{array}$ & $\begin{array}{l}-0.0019 \\
(1.85)\end{array}$ \\
\hline Percent Black & $\begin{array}{l}-0.0017 \\
(1.65)\end{array}$ & $\begin{array}{l}0.0061 \\
(3.72)\end{array}$ & $\begin{array}{l}-0.0037 \\
(2.26)\end{array}$ & $\begin{array}{l}-0.0041 \\
(2.82)\end{array}$ \\
\hline Percent Hispanic & $\begin{array}{l}0.0064 \\
(8.11)\end{array}$ & $\begin{array}{l}0.0057 \\
(3.65)\end{array}$ & $\begin{array}{l}0.006 \\
(4.71)\end{array}$ & $\begin{array}{l}0.005 \\
(4.45)\end{array}$ \\
\hline Real Income & $\begin{array}{l}-0.000027 \\
(4.43)\end{array}$ & $\begin{array}{l}-0.0000 \geq 1 \\
(2.16)\end{array}$ & $\begin{array}{l}-0.000017 \\
(1.69)\end{array}$ & $\begin{array}{l}-0.000039 \\
(4.56)\end{array}$ \\
\hline Percent Catholic & $\begin{array}{l}0.011 \\
(14.05)\end{array}$ & $\begin{array}{l}0.0076 \\
(6.17)\end{array}$ & $\begin{array}{l}-0.009 \\
(7.37)\end{array}$ & $\begin{array}{l}-0.011 \\
(10.15)\end{array}$ \\
\hline Percent Southern Baptist & $\begin{array}{l}-0.0017 \\
(1.50)\end{array}$ & $\begin{array}{l}0.0011 \\
(0.58)\end{array}$ & $\begin{array}{l}-0.0041 \\
(2.21)\end{array}$ & $\begin{array}{l}-0.005 \\
(3.07)\end{array}$ \\
\hline Percent Mormon & $\begin{array}{l}-0.0025 \\
(2.13)\end{array}$ & $\begin{array}{l}-0.0031 \\
(1.67)\end{array}$ & $\begin{array}{l}0.0065 \\
(3.13)\end{array}$ & $\begin{array}{l}-0.0044 \\
(2.48)\end{array}$ \\
\hline Percent Other Adherents & $\begin{array}{l}-0.010 \\
(0.18)\end{array}$ & $\begin{array}{l}0.010 \\
(4.75)\end{array}$ & $\begin{array}{l}-0.012 \\
(5.35)\end{array}$ & $\begin{array}{l}-0.011 \\
(5.52)\end{array}$ \\
\hline Percent Urban & $\begin{array}{l}-0.0026 \\
(2.80)\end{array}$ & $\begin{array}{l}-0.0051 \\
(3.80)\end{array}$ & $\begin{array}{l}0.0044 \\
(2.88)\end{array}$ & $\begin{array}{l}0.0000059 \\
(0.003)\end{array}$ \\
\hline Medium Cily & $\begin{array}{l}-0.129 \\
(6.19)\end{array}$ & $\begin{array}{l}-0.191 \\
(5.76)\end{array}$ & $\begin{array}{l}7.203 \\
(6.18)\end{array}$ & $\begin{array}{l}-0.181 \\
(6.15)\end{array}$ \\
\hline Large City & $\begin{array}{l}-0.495 \\
(10.84)\end{array}$ & $\begin{array}{l}-0.602 \\
(8.11)\end{array}$ & $\begin{array}{l}-0.752 \\
(10.17)\end{array}$ & $\begin{array}{l}-0.666 \\
(10.34)\end{array}$ \\
\hline Schooling & $\begin{array}{l}-0.02 ? \\
(6.21)\end{array}$ & $\begin{array}{l}-0.019 \\
(3.27)\end{array}$ & $\begin{array}{l}-0.033 \\
(5.63)\end{array}$ & $\begin{array}{l}-0.041 \\
(8.16)\end{array}$ \\
\hline Unemployment & $\begin{array}{l}-0.00099 \\
(1.70)\end{array}$ & $\begin{array}{l}-0.0011 \\
(1.25)\end{array}$ & $\begin{array}{l}-0.0015 \\
(1.77)\end{array}$ & $\begin{array}{l}-0.00035 \\
(0.42)\end{array}$ \\
\hline Time Dummy-862 & $\begin{array}{l}0.135 \\
(3.29)\end{array}$ & $\begin{array}{l}0.263 \\
(3.99)\end{array}$ & $\begin{array}{l}0.175 \\
(2.67)\end{array}$ & $\begin{array}{l}0.141 \\
(2.41)\end{array}$ \\
\hline Time Dummy-863 & $\begin{array}{l}0.265 \\
(6.82)\end{array}$ & $\begin{array}{l}0.466 \\
(0.16)\end{array}$ & $\begin{array}{l}0.351 \\
(5.75)\end{array}$ & $\begin{array}{l}0.291 \\
(5.28)\end{array}$ \\
\hline Time Dummy-864 & $\begin{array}{l}0.203 \\
(5.29)\end{array}$ & $\begin{array}{l}0.262 \\
(4.50)\end{array}$ & $\begin{array}{l}0.195 \\
(3.17)\end{array}$ & $\begin{array}{l}0.221 \\
(4.15)\end{array}$ \\
\hline Time Dummy-87T & $\begin{array}{l}0.0042 \\
(0.10)\end{array}$ & $\begin{array}{l}-0.099 \\
(0.70)\end{array}$ & $\begin{array}{l}0.0036 \\
(0.054)\end{array}$ & $\begin{array}{l}0.001 \\
(1.52)\end{array}$ \\
\hline Time Dummy-872 & $\begin{array}{l}0.087 \\
(2.01)\end{array}$ & $\begin{array}{l}0.173 \\
(2.43)\end{array}$ & $\begin{array}{l}0.112 \\
(1.62)\end{array}$ & $\begin{array}{l}0.091 \\
(1.48)\end{array}$ \\
\hline Time Dummy.873 & $\begin{array}{l}0.168 \\
(3.78)\end{array}$ & $\begin{array}{l}0.291 \\
(4.201\end{array}$ & $\begin{array}{l}0.135 \\
(1.07)\end{array}$ & $\begin{array}{l}0.186 \\
(2.66)\end{array}$ \\
\hline Time Dummy-874 & $\begin{array}{l}0.202 \\
(5.18)\end{array}$ & $\begin{array}{l}0.201 \\
(3.211\end{array}$ & $\begin{array}{l}0.130 \\
(2.04)\end{array}$ & $\begin{array}{l}0.143 \\
(2.54)\end{array}$ \\
\hline Time Dummy-881 & $\begin{array}{l}0.025 \\
(0.60)\end{array}$ & $\begin{array}{l}0.090 \\
(1.311)\end{array}$ & $\begin{array}{l}0.062 \\
(0.94)\end{array}$ & $\begin{array}{l}0.0021 \\
(0.063)\end{array}$ \\
\hline Time Dumny-882 & $\begin{array}{l}0.063 \\
(1.47)\end{array}$ & $\begin{array}{l}0.210 \\
(2.95)\end{array}$ & $\begin{array}{l}0.064 \\
(0.90)\end{array}$ & $\begin{array}{l}0.068 \\
(1.10)\end{array}$ \\
\hline
\end{tabular}




\begin{tabular}{|c|c|c|c|c|}
\hline Time Dummy-883 & $\begin{array}{l}0.198 \\
(4.79)\end{array}$ & $\begin{array}{l}0.622 \\
(6.40)\end{array}$ & $\begin{array}{l}0.207 \\
(0.13)\end{array}$ & $\begin{array}{l}0.226 \\
\text { (3.25) }\end{array}$ \\
\hline Time Dummy-884 & $\begin{array}{l}0.316 \\
(5.55)\end{array}$ & $\begin{array}{l}0.162 \\
(5.65)\end{array}$ & $\begin{array}{l}0.126 \\
(1.95)\end{array}$ & $\begin{array}{l}0.175 \\
(3.07) \\
\end{array}$ \\
\hline Time Dummy-891 & $\begin{array}{l}0.050 \\
(1.22)\end{array}$ & $\begin{array}{l}0.082 \\
(1.18)\end{array}$ & $\begin{array}{l}0.021 \\
(0.30)\end{array}$ & $\begin{array}{l}0.067 \\
(1.14)\end{array}$ \\
\hline Time Dummy-892 & $\begin{array}{l}0.078 \\
(1.90)\end{array}$ & $\begin{array}{l}0.366 \\
(4.01)\end{array}$ & $\begin{array}{l}0.0023 \\
(0.034)\end{array}$ & $\begin{array}{l}0.046 \\
(0.79)\end{array}$ \\
\hline Time Dummy-893 & $\begin{array}{l}0.216 \\
(5.53)\end{array}$ & $\begin{array}{l}0.408 \\
(6.42)\end{array}$ & $\begin{array}{l}0.213 \\
(3.33)\end{array}$ & $\begin{array}{l}0.225 \\
(4.03)\end{array}$ \\
\hline Time Dummy-894 & $\begin{array}{l}0.194 \\
(4.95)\end{array}$ & $\begin{array}{l}0.193 \\
(2.92)\end{array}$ & $\begin{array}{l}0.105 \\
(1.62)\end{array}$ & $\begin{array}{l}0.310 \\
(3.76)\end{array}$ \\
\hline F-Statistics & 39.575 & 31.996 & 27.929 & 31.391 \\
\hline Adjusted R-Square & 0.3862 & 0.6293 & 0.3954 & 0.4769 \\
\hline
\end{tabular}

Note: Absolute value of asymplotic i-sutistics is in partenteses. 
Table 4

Night Fatality

Demographic Models

\begin{tabular}{|c|c|c|c|c|}
\hline & AII Ages & ABe $\overline{181020}$ & 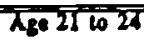 & A.5 25103 \\
\hline Intercept & $\begin{array}{l}-7.675 \\
(11.51)\end{array}$ & $\begin{array}{l}-5.655 \\
(5.41)\end{array}$ & $\begin{array}{l}-4.374 \\
(4.31)\end{array}$ & $\begin{array}{l}4.253 \\
(4.59)\end{array}$ \\
\hline Adverising & $\begin{array}{l}0.0000038 \\
(6.28)\end{array}$ & $\begin{array}{l}0.0000031 \\
(3.12)\end{array}$ & $\begin{array}{l}0.0000031 \\
(3.27)\end{array}$ & $\begin{array}{l}0.0000039 \\
(4.63)\end{array}$ \\
\hline Alcohol Price & $\begin{array}{l}-0.0018 \\
(1.68)\end{array}$ & $\begin{array}{l}0.0022 \\
(1.32)\end{array}$ & $\begin{array}{l}-0.0022 \\
(1.29)\end{array}$ & $\begin{array}{l}0.00014 \\
(0.16)\end{array}$ \\
\hline Percent Black & $\begin{array}{l}-0.0038 \\
(2.51)\end{array}$ & $\begin{array}{l}0.004 \\
(1.67)\end{array}$ & $\begin{array}{l}-0.0064 \\
(2.72)\end{array}$ & $\begin{array}{l}-0.0069 \\
(3.23)\end{array}$ \\
\hline Percent Hispanic & $\begin{array}{l}0.0018 \\
(1.54)\end{array}$ & $\begin{array}{l}-0.0021 \\
(1.10)\end{array}$ & $\begin{array}{l}0.00037 \\
(0.31)\end{array}$ & $\begin{array}{l}0.0016 \\
(0.99)\end{array}$ \\
\hline Real Income & $\begin{array}{l}-0.000017 \\
(1.96)\end{array}$ & $\begin{array}{l}-0.000019 \\
(1.40)\end{array}$ & $\begin{array}{l}-0.0000034 \\
(0.25)\end{array}$ & $\begin{array}{l}0.000025 \\
(2.07)\end{array}$ \\
\hline Percent Catholic & $\begin{array}{l}-0.0044 \\
(4.02)\end{array}$ & $\begin{array}{l}-0.00041 \\
(0.24)\end{array}$ & $(2.09)$ & $\begin{array}{l}-0.0045 \\
(3.09)\end{array}$ \\
\hline Percent Southern Baptist & $\begin{array}{l}-0.0014 \\
(0.81)\end{array}$ & $\begin{array}{l}0.00079 \\
(0.30)\end{array}$ & $\begin{array}{l}-0.0066 \\
(2.50)\end{array}$ & $\begin{array}{l}-0.0075 \\
\text { (3.11) }\end{array}$ \\
\hline Percent Mormon & $\begin{array}{l}-0.0053 \\
(2.70)\end{array}$ & $\begin{array}{l}0.00086 \\
(0.30)\end{array}$ & $\begin{array}{l}-0.010 \\
(0.13)\end{array}$ & $\begin{array}{l}-0.0056 \\
(2.06)\end{array}$ \\
\hline Percent Other Adherents & $\begin{array}{l}-0.0082 \\
(4.18)\end{array}$ & $\begin{array}{l}-0.0026 \\
(0.88)\end{array}$ & $\begin{array}{l}-0.0055 \\
(1.99)\end{array}$ & $\begin{array}{l}-0.0048 \\
(1.75)\end{array}$ \\
\hline Percent Urban & $\begin{array}{l}-0.00046 \\
(0.33)\end{array}$ & $\begin{array}{l}-0.0024 \\
(1.08)\end{array}$ & $\begin{array}{l}0.0034 \\
(1.62)\end{array}$ & $\begin{array}{l}0.0025 \\
(1.29)\end{array}$ \\
\hline Medium City & $\begin{array}{l}-0.183 \\
(5.97)\end{array}$ & $\begin{array}{l}-0.333 \\
(6.87)\end{array}$ & $\begin{array}{l}-0.288 \\
(6.14)\end{array}$ & $\begin{array}{l}-0.251 \\
(5.88)\end{array}$ \\
\hline Large City & $\begin{array}{l}-0.734 \\
(11.36)\end{array}$ & $\begin{array}{l}-0.966 \\
(8.85)\end{array}$ & $\begin{array}{l}0.967 \\
(9.38)\end{array}$ & $\begin{array}{l}-0.830 \\
(9.07)\end{array}$ \\
\hline Schooling & $\begin{array}{l}-0.027 \\
(5.16)\end{array}$ & $\begin{array}{l}-0.029 \\
(3.55)\end{array}$ & $\begin{array}{l}-0.037 \\
(4.50)\end{array}$ & $\begin{array}{l}0.031 \\
(6.99)\end{array}$ \\
\hline Unemployment & $\begin{array}{l}0.00073 \\
(0.95)\end{array}$ & $\begin{array}{l}-0.00023 \\
(0.19)\end{array}$ & $\begin{array}{l}0.0031 \\
(2.60)\end{array}$ & $\begin{array}{l}0.019 \\
(1.83)\end{array}$ \\
\hline Time Dummy-862 & $\begin{array}{l}0.184 \\
(3.03)\end{array}$ & $\begin{array}{l}0.161 \\
(1.67)\end{array}$ & $\begin{array}{l}0.248 \\
(2.63) \\
\end{array}$ & $\begin{array}{l}0.058 \\
(0.69) \\
\end{array}$ \\
\hline Time Dummy-863 & $\begin{array}{l}0.438 \\
(7.80)\end{array}$ & $\begin{array}{l}0.376 \\
(4.24)\end{array}$ & $\begin{array}{l}0.419 \\
(4.78)\end{array}$ & $\begin{array}{l}0.398 \\
(0.83)\end{array}$ \\
\hline Time Dummy-864 & $\begin{array}{l}0.298 \\
(5.27)\end{array}$ & $\begin{array}{l}0.255 \\
(2.86)\end{array}$ & $\begin{array}{l}0.297 \\
(0.39)\end{array}$ & $\begin{array}{l}0.200 \\
(2.55)\end{array}$ \\
\hline Time Dummy-87I & $\begin{array}{l}0.110 \\
(1.84)\end{array}$ & $\begin{array}{l}-0.076 \\
(0.71)\end{array}$ & $\begin{array}{l}0.035 \\
0.69)\end{array}$ & $\begin{array}{l}0.12 \\
(2.26)\end{array}$ \\
\hline Time Dummy-872 & $\begin{array}{l}0.088 \\
(1.37\end{array}$ & $\begin{array}{l}0.0037 \\
(0.036)\end{array}$ & $\begin{array}{l}0.102 \\
(1.00)\end{array}$ & $\begin{array}{l}-0.003 \\
(0.034)\end{array}$ \\
\hline Time Dummy-873 & $\begin{array}{l}0.182 \\
(2.82)\end{array}$ & $\begin{array}{l}0.176 \\
(1.69)\end{array}$ & $\begin{array}{l}0.161 \\
(1.59)\end{array}$ & $\begin{array}{l}0.069 \\
(0.76) \\
\end{array}$ \\
\hline Time Dummy-874 & $\begin{array}{l}0.212 \\
(3.63)\end{array}$ & $\begin{array}{l}0.101 \\
(1.08)\end{array}$ & $\begin{array}{l}0.257 \\
(2.62)\end{array}$ & $\begin{array}{l}0.172 \\
(2.13)\end{array}$ \\
\hline Tume Dummy-88I & $\begin{array}{l}0.072 \\
(1.18)\end{array}$ & $\begin{array}{l}-0.065 \\
(0.62)\end{array}$ & $\begin{array}{l}0.105 \\
(1.15)\end{array}$ & $\begin{array}{l}0.025 \\
(0.34)\end{array}$ \\
\hline Time Dummy-882 & $\begin{array}{l}0.110 \\
(1.69)\end{array}$ & $\begin{array}{l}0.037 \\
(0.35)\end{array}$ & $\begin{array}{l}0.199 \\
(1.95)\end{array}$ & $\begin{array}{l}0.076 \\
(0.84)\end{array}$ \\
\hline
\end{tabular}




\begin{tabular}{||l|l|l|l|l|}
\hline Time Dummy-883 & 0.279 & 0.280 & 0.217 & 0.181 \\
& $(4.57)$ & $(2.93)$ & $(2.27$ & $(2.15)$ \\
\hline Time Dummy-884 & 0.234 & 0.242 & 0.272 & 0.130 \\
& $(3.98)$ & $(2.62)$ & $(2.42)$ & $(1.59)$ \\
\hline Time Dummy-891 & 0.115 & 0.097 & 0.062 & 0.182 \\
& $(1.85)$ & $(0.97)$ & $(0.63)$ & $(1.20)$ \\
\hline Time Dummy-892 & 0.120 & 0.075 & 0.115 & 0.020 \\
& $(1.97)$ & $(0.78)$ & $(1.18)$ & $(0.24)$ \\
\hline Time Dummy-893 & 0.305 & 0.333 & 0.181 & 0.234 \\
& $(5.27$ & $(3.73)$ & $(1.96)$ & $(2.94)$ \\
\hline Time Dummy-894 & 0.214 & 0.169 & $(2.30)$ \\
\hline F-Statistics & $(3.65)$ & $(0.97)$ & $(1.84)$ & 17.722 \\
\hline Adjusted R-Square & 27.462 & 18.631 & 16.306 & 0.2937 \\
\hline
\end{tabular}

Nowe: Absolute value of asyajplotic i-statistics is in pareatheses. 
Table 5

All Fatality

Dummy Variable Models

\begin{tabular}{|c|c|c|c|c|}
\hline & All Ages & $\lambda_{\mathrm{Be}} 18$ 1020 & $\overline{A g e} 2 \prod_{10} \overline{2 A}$ & Aet $\overline{15}$ to 34 \\
\hline Tntercept & $\begin{array}{l}-9.694 \\
(111.17)\end{array}$ & $\begin{array}{l}-9.077 \\
(65.69) \\
\end{array}$ & $\begin{array}{l}8.811 \\
(64.60) \\
\end{array}$ & $\begin{array}{l}-9.363 \\
(75.24)\end{array}$ \\
\hline Adverising & $\begin{array}{l}0.0000013 \\
(3.13)\end{array}$ & $\begin{array}{l}0.00000057 \\
(0.89)\end{array}$ & $\begin{array}{l}0.0000016 \\
(2.50)\end{array}$ & $\begin{array}{l}0.0000017 \\
(2.98)\end{array}$ \\
\hline Alcohol Price & $\begin{array}{l}-0.0014 \\
(2.03) \\
\end{array}$ & $\begin{array}{l}0.0011 \\
(1.04)\end{array}$ & $\begin{array}{l}-0.0022 \\
(1.98) \\
\end{array}$ & $\begin{array}{l}-0.002 \\
(2.06) \\
\end{array}$ \\
\hline Medium City & $\begin{array}{l}-0.210 \\
(9.90) \\
\end{array}$ & $\begin{array}{l}-0.288 \\
(8.69)\end{array}$ & $\begin{array}{l}-0.212 \\
(8.57)\end{array}$ & $\begin{array}{l}0.262 \\
(8.63)\end{array}$ \\
\hline Large City & $\begin{array}{l}-0.371 \\
(11.44)\end{array}$ & $\begin{array}{l}-0.671 \\
(8.56)\end{array}$ & $\begin{array}{l}-0.7186 \\
(10.02)\end{array}$ & $\begin{array}{l}-0.753 \\
(10.48)\end{array}$ \\
\hline Mountain Region & $\begin{array}{l}0.134 \\
(3.87)\end{array}$ & $\begin{array}{l}-0.0051 \\
(0.091)\end{array}$ & $\begin{array}{l}0.046 \\
(0.44)\end{array}$ & $\begin{array}{l}0.097 \\
(1.99)\end{array}$ \\
\hline West North Central Region & $\begin{array}{l}-8.176 \\
(4.60)\end{array}$ & $\begin{array}{l}-0.102 \\
(1.75)\end{array}$ & $\begin{array}{l}-0.136 \\
(2.28)\end{array}$ & $\begin{array}{l}-0.166 \\
(3.43)\end{array}$ \\
\hline West South Central Region & $\begin{array}{l}.0 .189 \\
(6.65)\end{array}$ & $\begin{array}{l}-0.209 \\
(4.69)\end{array}$ & $\begin{array}{l}-0.249 \\
(5.57)\end{array}$ & $\begin{array}{l}-0.230 \\
(6.25)\end{array}$ \\
\hline East North Central Region & $\begin{array}{l}-0.296 \\
(12.28)\end{array}$ & $\begin{array}{l}0.288 \\
(7.59) \\
\end{array}$ & $\begin{array}{l}-0.309 \\
(8.15)\end{array}$ & $\begin{array}{l}0.139 \\
(7.63)\end{array}$ \\
\hline East South Central Region & $\begin{array}{l}0.143 \\
(3.81)\end{array}$ & $\begin{array}{l}0.164 \\
(2.83)\end{array}$ & $\begin{array}{l}0.068 \\
(1.12)\end{array}$ & $\begin{array}{l}0.197 \\
(3.65)\end{array}$ \\
\hline South Allantic Region & $\begin{array}{l}0.025 \\
(1.01)\end{array}$ & $\begin{array}{l}0.064 \\
(1.63)\end{array}$ & $\begin{array}{l}0.013 \\
(0.34)\end{array}$ & $\begin{array}{l}-0.0004 \\
(0.012)\end{array}$ \\
\hline Middle Atlantic Region & $\begin{array}{l}-0.286 \\
(10.29)\end{array}$ & $\begin{array}{l}0.337 \\
(7.71)\end{array}$ & $\begin{array}{l}-0.216 \\
(5.02)\end{array}$ & $\begin{array}{l}0.233 \\
(5.88)\end{array}$ \\
\hline New England Region & $\begin{array}{l}-0.291 \\
(7.10)\end{array}$ & $\begin{array}{l}0.185 \\
(2.94)\end{array}$ & $\begin{array}{l}-0.117 \\
(3.01)\end{array}$ & $\begin{array}{l}-0.195 \\
(+.99)\end{array}$ \\
\hline Time Dummy-862 & $\begin{array}{l}0.171 \\
(4.08)\end{array}$ & $\begin{array}{l}0.530 \\
(4.96)\end{array}$ & $\begin{array}{l}0.230 \\
(3.54)\end{array}$ & $\begin{array}{l}0.181 \\
(3.00)\end{array}$ \\
\hline Time Dummy-863 & $\begin{array}{l}0.292 \\
(7.34)\end{array}$ & $\begin{array}{l}0.479 \\
(7.63)\end{array}$ & $\begin{array}{l}0.395 \\
(6.49)\end{array}$ & $\begin{array}{l}0.323 \\
(5.64)\end{array}$ \\
\hline Time Dummy-864 & $\begin{array}{l}0.205 \\
(5.21)\end{array}$ & $\begin{array}{l}0.286 \\
(4.51)\end{array}$ & $\begin{array}{l}0.202 \\
(0.28)\end{array}$ & $\begin{array}{l}0.216 \\
(3.78)\end{array}$ \\
\hline Time Dummy-871 & $\begin{array}{l}-0.0078 \\
(0.19)\end{array}$ & $\begin{array}{l}0.069 \\
(0.98)\end{array}$ & $\begin{array}{l}0.011 \\
(0.17)\end{array}$ & $\begin{array}{l}0.056 \\
(0.96)\end{array}$ \\
\hline Time Dumny-872 & $\begin{array}{l}0.136 \\
(3.11)\end{array}$ & $\begin{array}{l}0.257 \\
(3.67)\end{array}$ & $\begin{array}{l}0.190 \\
(2.20)\end{array}$ & $\begin{array}{l}0.169 \\
(2.36)\end{array}$ \\
\hline Time Dummy-873 & $\begin{array}{l}0.120 \\
(4.98)\end{array}$ & $\begin{array}{l}0.398 \\
(5.71)\end{array}$ & $\begin{array}{l}0.217 \\
(3.13)\end{array}$ & $\begin{array}{l}0.212 \\
(3.46)\end{array}$ \\
\hline Time Dummy-874 & $\begin{array}{l}0.214 \\
(5.40)\end{array}$ & $\begin{array}{l}0.257 \\
(3.65)\end{array}$ & $\begin{array}{l}0.160 \\
(2.54)\end{array}$ & $\begin{array}{l}0.141 \\
(2.43)\end{array}$ \\
\hline Time Dummy-88I & $\begin{array}{l}0.0012 \\
(0.10)\end{array}$ & $\begin{array}{l}0.051 \\
(0.84)\end{array}$ & $\begin{array}{l}0.046 \\
(0.70)\end{array}$ & $\begin{array}{l}-0.037 \\
(0.60)\end{array}$ \\
\hline Time Dummy-882 & $\begin{array}{l}0.106 \\
(2.38)\end{array}$ & $\begin{array}{l}0.291 \\
(4.15)\end{array}$ & $\begin{array}{l}0.136 \\
(1.93)\end{array}$ & $\begin{array}{l}0.026 \\
(1.52)\end{array}$ \\
\hline Time Dummy-883 & $\begin{array}{l}0.233 \\
(5.61)\end{array}$ & $\begin{array}{l}0.485 \\
(7.45)\end{array}$ & $\begin{array}{l}0.266 \\
(4.10)\end{array}$ & $\begin{array}{l}0.247 \\
(4.12)\end{array}$ \\
\hline Time Dummy-884 & $\begin{array}{l}0.224 \\
(5.64)\end{array}$ & $\begin{array}{l}0.379 \\
(5.96)\end{array}$ & $\begin{array}{l}0.154 \\
(2.02)\end{array}$ & $\begin{array}{l}0.154 \\
(2.65)\end{array}$ \\
\hline
\end{tabular}




\begin{tabular}{||l|l|l|l|l|}
\hline Time Dummy-891 & 0.033 & 0.066 & 0.010 & 0.011 \\
\hline Time Dummy-892 & $(0.79)$ & $(0.95)$ & $(0.15)$ & $(0.18)$ \\
& 0.090 & 0.259 & 0.038 & 0.039 \\
& $(2.17)$ & $(4.58)$ & $(0.57)$ & $(0.65)$ \\
\hline Time Dummy-893 & 0.219 & 0.420 & 0.229 & 0.197 \\
& $(5.56)$ & $(6.67)$ & $(3.66)$ & $(3.46)$ \\
\hline Time Dummy-894 & 0.180 & 0.185 & 0.112 & 0.170 \\
& $(4.58)$ & $(2.83)$ & $(1.75)$ & 0.99 \\
\hline F-Statistics & 55.089 & 31.424 & 27.071 & 31.446 \\
\hline Adjusted R-Square & 0.549 & 0.4074 & 0.3789 & 0.4067 \\
\hline
\end{tabular}

Note: Absolute value of asynuptocic t.scatistics is ill parenclieses. 
Table 6

Night Fatality

Dummy Variable Models

\begin{tabular}{|c|c|c|c|c|}
\hline & तI Ages & Age I8 to 20 & Age $2 \longdiv { 1 0 2 4 }$ & Age 25 to $\overline{31}$ \\
\hline Intercept & $\begin{array}{l}-11.576 \\
(93.76)\end{array}$ & $\begin{array}{l}-10.064 \\
(51.35) \\
\end{array}$ & $\begin{array}{l}-10.146 \\
(52.94)\end{array}$ & $\begin{array}{l}-11.015 \\
(62.74)\end{array}$ \\
\hline Advertising & $\begin{array}{l}0.0000025 \\
(4.35)\end{array}$ & $\begin{array}{l}0.0000012 \\
(1.27)\end{array}$ & $\begin{array}{l}0.0000015 \\
(1.66)\end{array}$ & $\begin{array}{l}0.0000019 \\
(2.30)\end{array}$ \\
\hline Alcohol Price & $\begin{array}{l}-0.0011 \\
(1.16)\end{array}$ & $\begin{array}{l}-0.00046 \\
(0.30)\end{array}$ & $\begin{array}{l}0.00093 \\
(0.61)\end{array}$ & $\begin{array}{l}0.00031 \\
(0.22)\end{array}$ \\
\hline Medium City & $\begin{array}{l}-0.216 \\
(7.12)\end{array}$ & $\begin{array}{l}-0.3 \hbar 2 \\
(0.82)\end{array}$ & $\begin{array}{l}-0.315 \\
(6.88)\end{array}$ & $\begin{array}{l}-0.270 \\
(6.23)\end{array}$ \\
\hline Large City & $\begin{array}{l}-0.697 \\
(9.91) \\
\end{array}$ & $\begin{array}{l}-0.880 \\
(0.86)\end{array}$ & $\begin{array}{l}-0.930 \\
(8.60)\end{array}$ & $\begin{array}{l}-0.605 \\
(8.05)\end{array}$ \\
\hline Mouncain Region & $\begin{array}{l}0.112 \\
(2.15)\end{array}$ & $\begin{array}{l}0.048 \\
(0.56)\end{array}$ & $\begin{array}{l}-0.040 \\
(0.49)\end{array}$ & $\begin{array}{l}0.028 \\
(0.38)\end{array}$ \\
\hline West North Central Region & $\begin{array}{l}0.115 \\
0.22)\end{array}$ & $\begin{array}{l}0.325 \\
(4.08)\end{array}$ & $\begin{array}{l}0.136 \\
(1.97)\end{array}$ & $\begin{array}{l}0.151 \\
(2.08)\end{array}$ \\
\hline West South Central Region & $\begin{array}{l}0.004 \\
(0.10)\end{array}$ & $\begin{array}{l}0.020 \\
(0.32)\end{array}$ & $\begin{array}{l}0.164 \\
(2.58)\end{array}$ & $\begin{array}{l}0.073 \\
(1.31)\end{array}$ \\
\hline East North Central Region & $\begin{array}{l}-0.121 \\
(3.53)\end{array}$ & $\begin{array}{l}0.083 \\
(1.53) \\
\end{array}$ & $\begin{array}{l}0.067 \\
(1.65)\end{array}$ & $\begin{array}{l}-0.031 \\
(0.65)\end{array}$ \\
\hline East South Central Region & $\begin{array}{l}0.160 \\
(2.87)\end{array}$ & $\begin{array}{l}0.426 \\
(5.06)\end{array}$ & $\begin{array}{l}0.049 \\
(0.54)\end{array}$ & $\begin{array}{l}0.250 \\
(3.22)\end{array}$ \\
\hline South Allantic Region & $\begin{array}{l}0.076 \\
(2.12)\end{array}$ & $\begin{array}{l}0.143 \\
(2.44)\end{array}$ & $\begin{array}{l}0.103 \\
(1.88)\end{array}$ & $\begin{array}{l}0.082 \\
(1.64)\end{array}$ \\
\hline Middle Atlantic Region & $\begin{array}{l}0.114 \\
(2.90)\end{array}$ & $\begin{array}{l}0.074 \\
(1.17)\end{array}$ & $\begin{array}{l}0.062 \\
(1.04)\end{array}$ & $\begin{array}{l}0.022 \\
(0.40)\end{array}$ \\
\hline New England Region & $\begin{array}{l}0.028 \\
(0.50)\end{array}$ & $\begin{array}{l}0.176 \\
(2.00)\end{array}$ & $\begin{array}{l}0.110 \\
(1.31)\end{array}$ & $\begin{array}{l}0.017 \\
(0.21)\end{array}$ \\
\hline Time Dummy-862 & $\begin{array}{l}0.221 \\
(3.67)\end{array}$ & $\begin{array}{l}0.231 \\
(2.46)\end{array}$ & $\begin{array}{l}0.315 \\
(3.39)\end{array}$ & $\begin{array}{l}0.092 \\
(1.09)\end{array}$ \\
\hline Time Dummy-863 & $\begin{array}{l}0.760 \\
(8.23)\end{array}$ & $\begin{array}{l}0.416 \\
(4.78)\end{array}$ & $\begin{array}{l}0.472 \\
(5.45)\end{array}$ & $\begin{array}{l}0.314 \\
(4.00)\end{array}$ \\
\hline Time Dummy-864 & $\begin{array}{l}0.294 \\
(5.23)\end{array}$ & $\begin{array}{l}0.247 \\
(2.80)\end{array}$ & $\begin{array}{l}0.301 \\
(3.56)\end{array}$ & $\begin{array}{l}0.174 \\
(2.21)\end{array}$ \\
\hline Time Dummy-87! & $\begin{array}{l}0.085 \\
(1.42)\end{array}$ & $\begin{array}{l}-0.070 \\
(0.69)\end{array}$ & $\begin{array}{l}0.05 \\
(0.62)\end{array}$ & $\begin{array}{l}0.134 \\
(1.65)\end{array}$ \\
\hline Time Dummy-872 & $\begin{array}{l}0.132 \\
(2.09)\end{array}$ & $\begin{array}{l}0.087 \\
(0.88)\end{array}$ & $\begin{array}{l}0.200 \\
(2.02)\end{array}$ & $\begin{array}{l}0.045 \\
(0.51)\end{array}$ \\
\hline Time Dummy-873 & $\begin{array}{l}0.339 \\
(3.62)\end{array}$ & $\begin{array}{l}0.292 \\
(2.95)\end{array}$ & $\begin{array}{l}0.265 \\
(2.74)\end{array}$ & $\begin{array}{l}0.134 \\
(1.38)\end{array}$ \\
\hline Time Dummy-874 & $\begin{array}{l}0.307 \\
(3.59)\end{array}$ & $\begin{array}{l}0.116 \\
(1.27)\end{array}$ & $\begin{array}{l}0.252 \\
(3.30)\end{array}$ & $\begin{array}{l}0.146 \\
(1.84)\end{array}$ \\
\hline Time Dummy-88! & $\begin{array}{l}0.030 \\
(0.50)\end{array}$ & $\begin{array}{l}0.097 \\
(0.97)\end{array}$ & $\begin{array}{l}0.115 \\
(1.26)\end{array}$ & $\begin{array}{l}-0.055 \\
(0.65) \\
\end{array}$ \\
\hline Time Dummy-882 & $\begin{array}{l}0.143 \\
(2.23)\end{array}$ & $\begin{array}{l}0.117 \\
(1.17)\end{array}$ & $\begin{array}{l}0.257 \\
(3.00)\end{array}$ & $\begin{array}{l}0.104 \\
(1.17)\end{array}$ \\
\hline Time Dummy-883 & $\begin{array}{l}0.303 \\
(5.09)\end{array}$ & $\begin{array}{l}0.363 \\
(3.73)\end{array}$ & $\begin{array}{l}0.313 \\
(3.39)\end{array}$ & $\begin{array}{l}0.191 \\
(2.28)\end{array}$ \\
\hline Time Dummy-884 & $\begin{array}{l}0.215 \\
(3.73)\end{array}$ & $\begin{array}{l}0.256 \\
(2.03)\end{array}$ & $\begin{array}{l}0.274 \\
0.07\end{array}$ & $\begin{array}{l}0.064 \\
(0.79)\end{array}$ \\
\hline
\end{tabular}




\begin{tabular}{|c|c|c|c|c|}
\hline Time Dummy-89 & $\begin{array}{l}0.063 \\
(1.03)\end{array}$ & $\begin{array}{l}0.050 \\
(0.52)\end{array}$ & $\begin{array}{l}0.077 \\
(0.80)\end{array}$ & $\begin{array}{l}-0.011 \\
(0.21)\end{array}$ \\
\hline Time Dummy-892 & $\begin{array}{l}0.116 \\
(1.95)\end{array}$ & $\begin{array}{l}0.089 \\
(1.07)\end{array}$ & $\begin{array}{l}0.153 \\
(2.08)\end{array}$ & $\begin{array}{l}0.018 \\
(0.23)\end{array}$ \\
\hline Time Dummy-893 & $\begin{array}{l}0.281 \\
(4.96)\end{array}$ & $\begin{array}{l}0.325 \\
(3.95)\end{array}$ & $\begin{array}{l}0.216 \\
(2.41)\end{array}$ & $\begin{array}{l}0.166 \\
\text { (2.11) }\end{array}$ \\
\hline Time Dummy-894 & $\begin{array}{l}0.178 \\
(3.12)\end{array}$ & $\begin{array}{l}0.072 \\
(0.78)\end{array}$ & $\begin{array}{l}0.196 \\
(2.23)\end{array}$ & $\begin{array}{l}0.106 \\
(1.34)\end{array}$ \\
\hline F-Statistics & 26.886 & 20.146 & 16.678 & T3.0. \\
\hline Adjusted R-Square & 0.3683 & 0.3349 & 0.275 & 0.2456 \\
\hline
\end{tabular}

Nole: Absolute value of asymplotic t-stalistics is in parentheses. 
Table 7

Reduced Form OLS Madels

\begin{tabular}{|c|c|c|c|c|}
\hline & $\begin{array}{l}\text { Lopiric Fatality } \\
\text { Rate }\end{array}$ & $\begin{array}{l}\text { Logistle Fataity } \\
\text { Rate }\end{array}$ & Advertistos & Advertising \\
\hline Intercept & $\begin{array}{l}-7.375 \\
(18.45)\end{array}$ & $\begin{array}{l}-7.938 \\
(17.48)\end{array}$ & $\begin{array}{l}-347,285.920 \\
(6.95)\end{array}$ & $\begin{array}{l}-223.514 .900 \\
(3.90)\end{array}$ \\
\hline Adverising Drice & $\begin{array}{l}-0.0031 \\
(6.87)\end{array}$ & $\begin{array}{l}0.0027 \\
(6.36)\end{array}$ & $\begin{array}{l}-736.066 \\
(13.24)\end{array}$ & $\begin{array}{l}-705.111 \\
(12.97)\end{array}$ \\
\hline TV Stations & $\begin{array}{l}-0.021 \\
(2.08)\end{array}$ & $\begin{array}{l}-0.003 \\
(0.30)\end{array}$ & $\begin{array}{l}11.731 .265 \\
(9.26)\end{array}$ & $\begin{array}{l}11.636 .181 \\
(9.33)\end{array}$ \\
\hline RADTO Stations & $\begin{array}{l}0.0027 \\
(5.94)\end{array}$ & $\begin{array}{l}0.0022 \\
(4.65)\end{array}$ & $\begin{array}{l}669.750 \\
(11.64)\end{array}$ & $\begin{array}{l}735.304 \\
(12.48)\end{array}$ \\
\hline Alcohol Price & $\begin{array}{l}-0.014 \\
(2.18)\end{array}$ & $\begin{array}{l}-0.0013 \\
(1.96)\end{array}$ & $\begin{array}{l}63.977 \\
(0.80)\end{array}$ & $\begin{array}{l}180.176 \\
(2.15)\end{array}$ \\
\hline Percent Black & $\begin{array}{l}-0.0008 \\
(0.88)\end{array}$ & $\begin{array}{l}-0.00012 \\
(0.12)\end{array}$ & $\begin{array}{l}210.189 \\
(2.46)\end{array}$ & $\begin{array}{l}210.516 \\
(1.66)\end{array}$ \\
\hline Percent Hispanic & $\begin{array}{l}0.0072 \\
(9.83)\end{array}$ & $\begin{array}{l}0.0058 \\
(6.85)\end{array}$ & $\begin{array}{l}170.781 \\
(1.87)\end{array}$ & $\begin{array}{l}-165.066 \\
(1.55)\end{array}$ \\
\hline Real Income & $\begin{array}{l}-0.000017 \\
(3.08)\end{array}$ & $\begin{array}{l}-0.000014 \\
(2.66)\end{array}$ & $\begin{array}{l}\text { T.798 } \\
\text { (2.55) }\end{array}$ & $\begin{array}{l}1.263 \\
(2.71)\end{array}$ \\
\hline Percent Catholic & $\begin{array}{l}-0.010 \\
(13.62)\end{array}$ & $\begin{array}{l}-0.0076 \\
0.18)\end{array}$ & $\begin{array}{l}107.054 \\
(1.19)\end{array}$ & $\begin{array}{l}24.807 \\
(6.22)\end{array}$ \\
\hline Percent Southern Baptist & $\begin{array}{l}-0.00037 \\
(0.36)\end{array}$ & $\begin{array}{l}0.0015 \\
(1.14)\end{array}$ & $\begin{array}{l}102.291 \\
(0.78)\end{array}$ & $\begin{array}{l}5.636 \\
(0.034)\end{array}$ \\
\hline Percent Mormon & $\begin{array}{l}-0.0037 \\
(3.40)\end{array}$ & $\begin{array}{l}0.0045 \\
(4.03)\end{array}$ & $\begin{array}{l}-287.391 \\
(2.14)\end{array}$ & $\begin{array}{l}.345 .351 \\
(2.46)\end{array}$ \\
\hline Percent Other Adherents & $\begin{array}{l}-0.0082 \\
(6.72)\end{array}$ & $\begin{array}{l}-0.002 \\
(1.22)\end{array}$ & $\begin{array}{l}37.17 \\
(2.43)\end{array}$ & $\begin{array}{l}-239.430 \\
(1.11)\end{array}$ \\
\hline Percent Urban & $\begin{array}{l}-0.0011 \\
(1.37)\end{array}$ & $\begin{array}{l}0.0000063 \\
(0.007)\end{array}$ & $\begin{array}{l}458.487 \\
(4.38)\end{array}$ & $\begin{array}{l}102.315 \\
(0.91)\end{array}$ \\
\hline Medium City & $\begin{array}{l}-0.074 \\
(3.73)\end{array}$ & $\begin{array}{l}-0.089 \\
(4.65)\end{array}$ & $\begin{array}{l}6.525 .584 \\
(2.64)\end{array}$ & $\begin{array}{l}5.901 .160 \\
(1.61)\end{array}$ \\
\hline Large City & $\begin{array}{l}-0.369 \\
(8.20)\end{array}$ & $\begin{array}{l}-0.351 \\
(7.81)\end{array}$ & $\begin{array}{l}30.674 .158 \\
(5.45)\end{array}$ & $\begin{array}{l}24.250 .300 \\
(4.28)\end{array}$ \\
\hline Schooling & $\begin{array}{l}-0.014 \\
(4.34)\end{array}$ & $\begin{array}{l}-0.016 \\
(3.88)\end{array}$ & $\begin{array}{l}1.642 .662 \\
(4.04)\end{array}$ & $\begin{array}{l}1.063 .676 \\
(2.40)\end{array}$ \\
\hline Unemployment & $\begin{array}{l}-0.00025 \\
(0.52)\end{array}$ & $\begin{array}{l}0.0023 \\
(4.10)\end{array}$ & $\begin{array}{l}294.023 \\
(4.90)\end{array}$ & $\begin{array}{l}-134.332 \\
(1.86)\end{array}$ \\
\hline Mountain Region & & $\begin{array}{l}0.153 \\
(5.48)\end{array}$ & & $\begin{array}{l}-5.793 .3512 \\
(1.38)\end{array}$ \\
\hline West North Central Region & & $\begin{array}{l}-0.0023 \\
(0.06)\end{array}$ & & $\begin{array}{l}-14.983 .582 \\
(2.84)\end{array}$ \\
\hline West South Central Region & & $\begin{array}{l}-0.222 \\
(6.06)\end{array}$ & & $\begin{array}{l}6.951 .7399 \\
(1.50)\end{array}$ \\
\hline East North Central Region & & $\begin{array}{l}-0.131 \\
(3.80)\end{array}$ & & $\begin{array}{l}-1.400 .051 \\
(0.33)\end{array}$ \\
\hline East South Central Region & & $\begin{array}{l}-0.060 \\
(1.28)\end{array}$ & & $\begin{array}{l}7.755 .011 \\
(1.32)\end{array}$ \\
\hline South Alantic Region & & $\begin{array}{l}0.015 \\
(0.48)\end{array}$ & & $\begin{array}{l}-6.816 .193 \\
(1.72)\end{array}$ \\
\hline Middle Atlantic Region & & $\begin{array}{l}-0.071 \\
(1.81)\end{array}$ & & $\begin{array}{l}-21.986 .351 \\
(5.89)\end{array}$ \\
\hline New England Region & & $\begin{array}{l}0.017 \\
(0.33)\end{array}$ & & $\begin{array}{l}-36.999 .644 \\
(8.82)\end{array}$ \\
\hline Time Dummy-862 & $\begin{array}{l}0.227 \\
(6.54)\end{array}$ & $\begin{array}{l}0.230 \\
(7.06)\end{array}$ & $\begin{array}{l}38,336.187 \\
(\mathbf{8 . 8 3 )}\end{array}$ & $\begin{array}{l}37.669 .345 \\
(9.15) .\end{array}$ \\
\hline Time Dummy-863 & $\begin{array}{l}0.369 \\
(10.71)\end{array}$ & $\begin{array}{l}0.375 \\
(11.56)\end{array}$ & $\begin{array}{l}36.998 .44 \\
(8.57)\end{array}$ & $\begin{array}{l}35,324.479 \\
(8.62)\end{array}$ \\
\hline
\end{tabular}




\begin{tabular}{|c|c|c|c|c|}
\hline Time Dummy-864 & $\begin{array}{l}0.253 \\
(6.68)\end{array}$ & $\begin{array}{l}0.244 \\
(0.45)\end{array}$ & $\begin{array}{l}10.398 .726 \\
(2.36)\end{array}$ & $\begin{array}{l}.274 .832 \\
(2.00)\end{array}$ \\
\hline Time Dummy-871 & $\begin{array}{l}.0 .026 \\
(0.70)\end{array}$ & $\begin{array}{l}-0.0082 \\
(0.24)\end{array}$ & $\begin{array}{l}-10.619 .313 \\
(2.30)\end{array}$ & $\begin{array}{l}-13.291 .126 \\
0.03)\end{array}$ \\
\hline Time Dummy-872 & $\begin{array}{l}0.196 \\
(5.59)\end{array}$ & $\begin{array}{l}0.216 \\
(6.53)\end{array}$ & $\begin{array}{l}\text { का,599.496 } \\
(10.85)\end{array}$ & $\begin{array}{l}4.612 .730 \\
(10.69)\end{array}$ \\
\hline Time Dummy-873 & $\begin{array}{l}0.294 \\
(8.53) \\
\end{array}$ & $\begin{array}{l}0.318 \\
(9.75)\end{array}$ & $\begin{array}{l}35,016.179 \\
(12.75)\end{array}$ & $\begin{array}{l}31.459 .226 \\
(12.51)\end{array}$ \\
\hline Time Dummy-874 & $\begin{array}{l}0.241 \\
(6.89)\end{array}$ & $\begin{array}{l}0.267 \\
(8.08)\end{array}$ & $\begin{array}{l}\text { T7.678.T34 } \\
(4.04)\end{array}$ & $\begin{array}{l}\text { TR.072.839 } \\
\text { (0.37) }\end{array}$ \\
\hline Time Dummy-881 & $\begin{array}{l}-0.018 \\
(0.48) \\
\end{array}$ & $\begin{array}{l}0.014 \\
(0.39)\end{array}$ & $\begin{array}{l}+14.690 .166 \\
(0.16)\end{array}$ & $\begin{array}{l}-18.978 .194 \\
(4.27)\end{array}$ \\
\hline Time Dummy-882 & $\begin{array}{l}0.161 \\
(4.51)\end{array}$ & $\begin{array}{l}0.196 \\
(5.76)\end{array}$ & $\begin{array}{l}75,723.363 \\
(10.22)\end{array}$ & $\begin{array}{l}41,393.954 \\
(9.65)\end{array}$ \\
\hline Time Dummy-883 & $\begin{array}{l}0.281 \\
(8.02)\end{array}$ & $\begin{array}{l}0.316 \\
(9.40)\end{array}$ & $\begin{array}{l}36.834 .089 \\
(1.40)\end{array}$ & $\begin{array}{l}32.238 .740 \\
(7.66)\end{array}$ \\
\hline Time Dummy-884 & $\begin{array}{l}0.239 \\
(6.73)\end{array}$ & $\begin{array}{l}0.275 \\
(8.09)\end{array}$ & $\begin{array}{l}12.0 \% 8.771 \\
(2.72)\end{array}$ & $\begin{array}{l}7,931.417 \\
(1.86)\end{array}$ \\
\hline Time Dumny-891 & $\begin{array}{l}0.0017 \\
(0.046)\end{array}$ & $\begin{array}{l}0.038 \\
(1.07)\end{array}$ & $\begin{array}{l}-15.255 .360 \\
(3.27)\end{array}$ & $\begin{array}{l}-19.172 .748 \\
(4.27)\end{array}$ \\
\hline Time Dummy-892 & $\begin{array}{l}0.118 \\
(3.24)\end{array}$ & $\begin{array}{l}0.1352 \\
(4.39)\end{array}$ & $\begin{array}{l}20.562 .210 \\
(4.50)\end{array}$ & $\begin{array}{l}16.266 .827 \\
(0.71)\end{array}$ \\
\hline Time Dummy-893 & $\begin{array}{l}0.259 \\
(7.25)\end{array}$ & $\begin{array}{l}0.293 \\
(8.64)\end{array}$ & $\begin{array}{l}13.932 .605 \\
(3.56)\end{array}$ & $\begin{array}{l}10.649 .353 \\
(2.53)\end{array}$ \\
\hline Time Dummy-894 & $\begin{array}{l}0.190 \\
(5.33)\end{array}$ & $\begin{array}{l}0.224 \\
(6.60)\end{array}$ & $\begin{array}{l}3.151 .264 \\
(0.17)\end{array}$ & $\begin{array}{l}-1.187 .201 \\
(0.28)\end{array}$ \\
\hline F-Statistics & 68.11 & 63.493 & 120.494 & 112.792 \\
\hline Adjusted R-Square & 0.6344 & 0.6772 & 0.76 & 0.7843 \\
\hline
\end{tabular}

Note: Absolute value of asymptotic i-statistics is in paseacheses. 


\section{REFERENCES}

Ackoff, R. and J. Emshoff, "Advertising Research at Anheuser-Busch, Inc. (1963-68)", Sloan Management Review, Winter, 1975, 1-15.

Arbitron, Description of Methodology, New York, NY: The Arbitron Company, 1990.

Atkin, C. "Alcoholic-Beverage Advertising: Its Content and Impact", in Control Issues in Alcohol Abuse Prevention: Strategies for States and Communities, Ed. Harold Holder, Greenwich, CT: JAI Press Inc., 1987, 267-87.

Bass, F. and R. Leone, "Temporal Aggregation, the Data Interval Bias, and Empirical Estimation of Bimonthly Relations from Annual Data", Management Science, 29, 1983, 1-11.

Berndt, E. The Practice of Economerrics: Classic and Contemporary, Reading MA: Addison-Wesley Publishing Co. 1991.

Bourgeois, J. and J. Barnes, "Does Advertising Increase Alcohol Consumption?", Journal of Advertising Research 19, 1979, 19-29.

Chaloupka, F., H., Saffer, and M. Grossman, "Alcohol Control Policies and Motor Vehicle Fatalities". Journal of Legal Studies, 22, 1993, 161-186.

Duffy, M., "The Demand for Alcoholic Drink in the United Kingdom, 1963-78", Applied Economics. 15, 1983, 125-140.

Duffy, M., "Advertising and the Inter-product Distribution of Demand", European Economic Review. 31, 1987, 1051-1070.

Duffy, M. "Advertising in Demand Systems: Testing a Galbraithian Hypothesis", Applied Economics. 23, 1991, 485-496.

Ehrlich, I., L. Fisher, "The Derived Demand for Advertising: A Theoretical and Empirical Investigation". American Economic Review, 72, 3, 1982, 366-388.

Franke, G. and G. Wilcox, "Alcoholic Beverage Advertising and Consumption in the United States, 1964-1984", Journal of Advertising, 16, 1987, 22-30.

Glenmary Research Center, Churches and Church Membership in the United States, Glenmary Research Center, Altanta Georgia, 1980.

Glenmary Research Center, Churches and Church Membership in the United States, Glenmary Research Center, Altanta Georgia, 1990.

Grabowski, H. "The Effects of Advertising on the Interindustry Distribution of Demand", Explorations in Economic Research, 3, 21-75 1976. 
Hernon, P. and T. Ganey, Under The Influence, Simon and Schuster, New York, 1991.

Johnson, L., "Alternative Econometric Estimates of the Effects of Advertising on the Demand for Alcoholic Beverages in the United Kingdom", International Journal of Advertising, 4, 1985, 19-25.

Lambin, J., Advertising. Competition and Market Conduct in Oligopoly Over Time, North-Holland. Amsterdam, 1976.

Maddala, G.S. Limited Dependent and Qualitative Variables in Econometrics. Cambridge, England: Cambridge University Press, 1983.

McGuiness, T. "An Econometric Analysis of Total Demand for Alcoholic Beverages in the U.K. 19561975", Journal of Industrial Economics, 29, 85-105. 1980.

McGuiness, T. "The Demand for Beer, Spirits and Wine in the UK, 1956-1979", in Grant, Plant and Williams, eds. Economics and Alcohol Gardner Press, Inc. New York. 1983, $238-242$.

Ogborne, A., and Smart, R., Will Restrictions on Alcohol Advertising Reduce Alcohol Consumption?", British Journal of Addiction, 75, 293-296 1980.

Ornstein, S. and Hanssens, D., "Alcohol Control Laws and the Consumption of Distilled Spirits and Beer", Journal of Consumer Research, 12, 200-213. 1985.

Saffer, H., "Alcohol Advertising Bans and Alcohol Abuse: An International Perspective", Lournal of Health Economics, 10., 65-79, 1991.

Saffer, H., "Alcohol Advertising Bans and Alcohol tbuse: Reply", Journal of Health Economics. 12., 229-234, 1993.

Saffer, H. "Alcohol Advertising and Alcohol Abuse: Econometric Evidence", National Institute on Alcohol Abuse and Alcoholism, Washington, D.C.. forthcoming, 1994.

Selvanathan, E., "Advertising and Alcohol Demand in the UK: Further Results", International Journal of Advertising, 8, 1989, 181-188.

Schmalensee, R. The Economics of Advertising, Amsterdam: North-Holland, 1972.

Smart, R. "Does Alcohol Advertising Affect Overall Consumption? A Review of Empirical Studies", Journal of Studies on Alcohol, 49, 314-23, 1988.

Smart, R. and Cutler R., "The Alcohol Advertising Ban in British Columbia: Problems and Effects on Beverage Consumption", British Journal of Addiction, 71, 13-21 1976.

Walsh B., "The Demand for Alcohol in the UK: A Comment", The Journal of Industrial Economics, vol. 30, no. 4, June 1982 .

Young, D., "Alcohol Advertising Bans and Alcohol Abuse: Comment", Journal of Health Economics, 12., 213-228, 1993. 